\title{
Wetland Vegetation Establishment in L-Lake
}

\author{
by \\ Steven R. Kroeger \\ Savannah River Ecology Laboratory
}

July, 1990

\section{DISCLAIMER}

This report was prepared as an account of work sponsored by an agency of the United States Government. Neither the United States Government nor any agency thereof, nor any of their employees, makes any warranty, express or implied, or assumes any legal liability or responsibility for the accuracy, completeness, or usefulness of any information, apparatus, product, or process disclosed, or represents that its use would not infringe privately owned rights. Reference herein to any specific commercial product, process, or service by trade name, trademark, manufacturer, or otherwise does not necessarily constitute or imply its endorsement, recommendation, or favoring by the United States Government or any agency thereof. The views and opinions of authors expressed herein do not necessarily state or reflect those of the United States Government or any agency thereof.

\section{MASTER}




\section{EXECUTIVE SUMMARY}

Wetland vegetation was transplanted from PAR Pond to L-Lake between January and August, 1987. Approximately 100,000 individual plants representing over 40 species were transplanted along the southern shoreline. Three zones of vegetation were created: 1) submersed/floating-leaved, 2) emergent, 3) upper emergent/shrub. During the summers of $1987,1988,1989$, the Savannah River Ecology Laboratory sampled the vegetation in 54 permanent transects located in planted $(\mathrm{N}=32)$ and unplanted areas $(\mathrm{N}=22)$. The 1989 vegetation data from L-Lake were compared to 1985 data from PAR Pond.

\section{Submersed and Floating-leaved Vegetation}

Nine species of submersed and floating-leaved plants were transplanted into this zone. American lotus (Nelumbo lutea), a floating-leaved species, and water celery (Vallisneria americana), a submersed plant, were the surviving species in 1989. Wave action and low initial planting apparently made establishment of some species difficult.

Colonization has occurred rapidly in this zone. In $1987,95 \%$ of the plots sampled had no vegetation present. By 1989 , the percentage of empty plots had declined to $62 \%$, due to expansion of water celery and American lotus. In 1987, mean cover per plot was $1 \%$, however this increased to $22 \%$ by 1989 . No submersed or floating-leaved vegetation was found in the unplanted areas.

Comparing the vegetation of L-Lake with PAR Pond shows that there are few similarities. American lotus is well established in both reservoirs but PAR Pond has a greater species diversity. Water celery is well established in L-Lake but was not sampled in PAR Pond. Many emergent species occur in the deeper water in PAR Pond and these 
same species are expected to occur in the deeper waters of L-Lake given time. Cattail (Typha latifolia) already is established in L-Lake in water greater than $30 \mathrm{~cm}(1 \mathrm{ft})$.

\section{Emergent Vegetation}

Most species were successfully transplanted in this zone. In $1987,32 \%$ of the plots sampled in planted areas were without vegetation, but by 1989 this had declined to $16 \%$. Mean cover per plot increased from $22 \%$ in 1987 to $40 \%$ in 1988 and remained the same for 1989. Emergent vegetation is becoming established slowly in unplanted shoreline areas. Alligator weed (Altemanthera philoxeroides), water pennywort (Hydrocoryle umbellata) and cattail were the only emergent species in unplanted areas with absolute frequencies greater than $5 \%$ in 1989 . The frequency of empty plots remained relatively constant since 1987 , approximately $85 \%$ per year.

The emergent vegetation of L-Lake is similar in composition to the emergent vegetation of PAR Pond. The Panicum/Sacciolepsis ( $P$. hemitomon and S. striata) grasses were the most important component of the vegetation in both sites. Water celery was important in L-Lake but not sampled in PAR Pond.

\section{Upper Emergent/Shrub Vegetation}

All species planted in 1987 were present in 1989. Willow (Salix nigra) and the Panicum/Sacciolepsis grasses were the most important species in this vegetation zone. This zone was sufficiently vegetated with terrestrial species so that the proportion of barren plots was always very low. Mean cover per plot in planted areas increased from $59 \%$ in 1987 to $69 \%$ in 1988 and then decreased to $55 \%$ in 1989 . Damage to vegetation 
by feral pigs was noted in 1989 , but additional unknown factors may have contributed to the decrease in cover. Willow was the dominate shrub.

\section{Conclusions}

1.) American lotus and water celery are well established along some shoreline areas where it was planted.

2.) Additional time is necessary for the vegetation in water greater than $30 \mathrm{~cm}(1 \mathrm{ft})$ deep to develop and become similar in compostion to the vegetation in PAR Pond.

3.) No vegetation in water greater than $30 \mathrm{~cm}$ deep is present along areas of shoreline which were not planted.

4.) Emergent vegetation is well established only along areas of shoreline where it was planted.

5.) Emergent vegetation is becoming established slowly along areas of shoreline which were not planted.

6.) Emergent vegetation of L-Lake in planted areas is similar to emergent vegetation in PAR Pond.

7.) Willow is the dominate shrub. 


\section{TABLE of CONTENTS}

Executive Summary.

Introduction. .i

Methods. .4

Planting. . .4

Vegetation Sampling.....................................................................................................

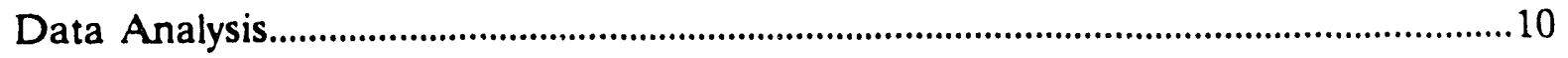

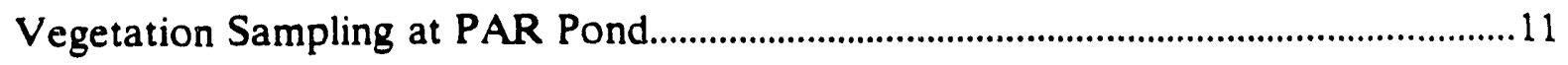

Results and Discussion........................................................................................................11

Submersed and Floating-leaved Vegetation........................................................................11

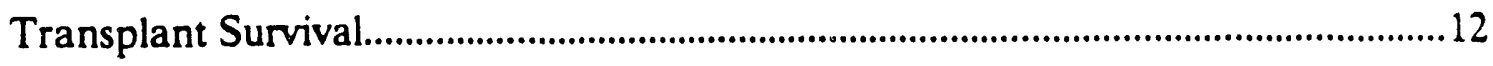

Changes from 1987 to 1989 in Planted Areas............................................................12

Comparison Between Planted and Unplanted Areas.................................................16

Comparison with Submersed/Floating-leaved Vegetation at PAR Pond...................16

Emergent Vegetation...............................................................................................................19

Transplant Survival.................................................................................................19

Changes from 1987 to 1989 in Planted Areas.............................................................19

Comparison Between Planted and Unplanted Areas................................................22

Comparison with Emergent Vegetation at PAR Pond..............................................24

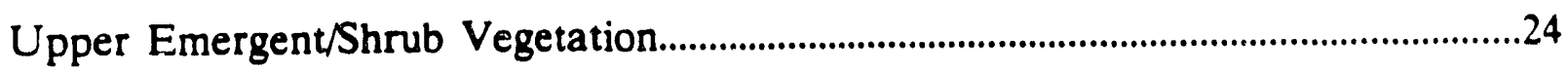

Transplant Survival..................................................................................................26

Changes from 1987 to 1989 in Planted Areas............................................................26

Comparison Between Planted and Unplanted Areas.................................................28

Summary. . .28

References.

APPENDIX A. Maps of Shoreline Vegetation. . .32

Species codes used on the topographic maps...........................................................................33

APPENDIX B. Vegetation sampled during 1987, 1988, and 1989. 


\section{INTRODUCTION}

The Department of Energy's (DOE) decision to restart L-Reactor resulted in the construction of L-Lake, a 400 ha (1,000 acre) once-through cooling reservoir to cool thermal effluents before entry into Steel Creek. To obtain necessary federal and state permits for thermal effluent discharge into the lake, DOE was required to meet requirements mandated by Section 316b of the Water Pollution Control Act Amendments of 1972. One requirement was the establishment of a balanced biological community (BBC). A primary component of a $\mathrm{BBC}$ is vegetation because it forms the base for aquatic food chains, provides habitat for animals and functions in nutrient cycling.

To augment natural establishment of a wetland plant community, DOE requested that the University of Georgia's Savannah River Ecology Laboratory (SREL) implement planting of wetland vegetation along the shores of L-Lake. A panel of experts in the areas of wetland ecology and restoration was invited to the Savannah River Site and developed a management plan for establishing an appropriate wetland plant community (Whigham et al. 1985). In addition, the panel recommended that plants for L-Lake be transplanted from PAR Pond, a recirculating cooling reservoir.

The panel recommended that plants for L-Lake be transplanted from PAR Pond for the following reasons. First, its location near L-Lake facilitated logistics. Second, its naturally established vegetation, portions of which have been exposed to thermal effluents for 30 years, may be more thermally tolerant than plants from natural sources. Finally, species found in PAR Pond are representative of natural wetland species in the region. 
L-Lake was completed in October, 1985. The Savannah River Ecology Laboratory requested competitive bids from private contractors to implement the transplanting project in 1985. A topographic survey of the shoreline of the southern half of the lake was made in 1986 to aid the contractor in transplanting.

Southern Tier Consulting, a firm specializing in the establishment of wetland plant communities, was selected for the project. Between January and August, 1987, approxiimately 4200 meters $(14,000 \mathrm{ft})$ of L-Lake shoreline were planted with 100,000 plants representing over 40 species.

The panel also proposed that zones of vegetation be established to represent species patterns found in PAR Pond and natural lakes (Whigham et al. 1985). These zones are differentiated by species composition and may be controlled by water depth. Three zones of vegetation were established (Fig 1.). Trees, shrubs and some emergents formed the upper emergent/shrub zone. This zone lies above the waterline, but can flood periodically. The emergent zone consists of erect species (e.g. cattail) which are present mostly in shallow water. The third zone consists of floating-leaved (e.g. water lilies) and submersed species, and occurs in deeper water.

In August 1987, SREL sampled the shoreline vegetation of L-Lake to assess the survival of transplants and the rate of colonization of new areas. Vegetation was also sampled during the summers of 1988 and 1989 along permanent transects located in both planted and unplanted areas of shoreline. This report focuses on 1) plant survival since $1987,2)$ changes in community composition between 1987 and 1989 in planted areas, 3) differences in vegetation siructure between planted and unplanted areas in 1989, and 4) 


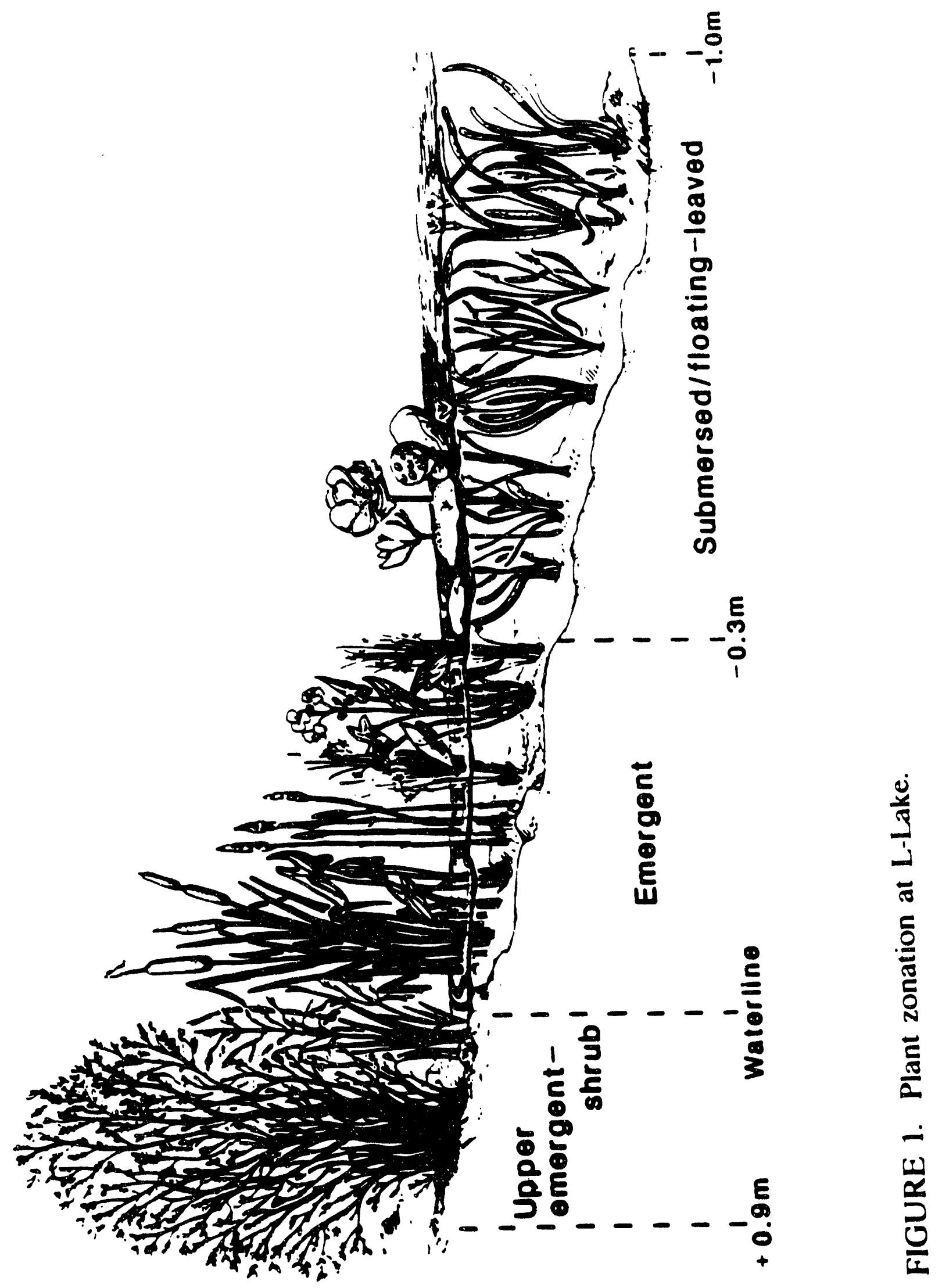


a comparison of the vegetation in the submersed/floating-leaved and emergent zones of L-Lake and PAR Pond.

\section{METHODS}

\section{Planting}

The management plan for establishment of littoral/wetland vegetation on the L-Lake shoreline (Whigham et al. 1985) was used as a guide for planting. The (spatially) continuous planting option was adopted; this option recommended that all available portions of the southern half of L-Lake be planted. The northern half of the lake was not planted because it is thermally impacted and survival of the transplants was expected to be low. About $10 \%$ of the southern shoreline was not planted because it had prior designated use for regulatory compliance monitoring (i.e. fish electroshocking and vegetation monitoring).

PAR Pond and commercial nurseries were used as sources of plant material. Per€nnial herbaceous plants were excavated by hand from PAR Pond, but trees, one emergent herb (Sagittaria latifolia) and seed of some grasses were obtained from commercial sources. Species planted are listed in Table 1. Maps of planting locations are in Appendix A. Each individual was planted with a ten gram tablet of timed-release Agriform fertilizer (20-10-5). Planting occurred from January through August, 1987. Emergent plants were spaced at $60 \mathrm{~cm}(2 \mathrm{ft})$ centers and floating-leaved species at $1.2 \mathrm{~m}$ (4 ft) centers. Most emergents were planted in blocks containing one species. A block

was a rectangular area $15 \mathrm{~m}(50 \mathrm{ft})$ long and the width varied according to the slope of the shoreline. Seed densities for grasses are not known since they were spread by hand. 
TABLE 1. Species and quantities planted at L-Lake by Southern Tier Consulting between between January and Aurust, 1987. ("Planted as seed.)

Scientific name

Submersed/noating-leaved zone

Brasenia schreberi

Eleocharis acicularis

Najas gracillima

Nelumbo lutea

Nymphaea odorata

Nymphoides aquatica

Potamogeton pulcher

Potamogeton vaseyi

Vallisneria americana
Common name

Quantity

Water shield

Spike rush

Bushy pondweed

American lotus

White waterlily

Floating heart

Pondweed

Pondweed

Water celery planted

$<1000$

$<100$

$<1000$

$>2000$

$<100$

$<1000$

$<100$

$>2000$
$<2000$

\section{Emergent zone}

Axonopus sp.

Carpet grass

$10 \mathrm{lbs}^{\star}$

Bacopa caroliniana

Bacopa

$>2000$

Carex comosa

Sedge

$<2000$

Carex glaucescens

Sedge

$<100$

Dulichium arundinaceum

Echinochloa crusgalli

Three-way sedge

$<100$

Wild millet

$25 \mathrm{lbs}$

Echinodorus cordifolius

Burhead

$<100$

Eleocharis equisetoides

Eleocharis quadrangulata

Erianthus giganteus

Spike rush

$<2000$

Spike rush

$<2000$

Beard grass

$<100$

Glyceria striata

Manna grass

$<100$

Grass

$<1000$ 
TABLE 1 continued.

Scientific name

Hydrocotyle umbellata

Juncus acuminatus

Juncus brachycarpus

Juncus effusus

Juncus diffusisimus

Leerisa oryzoides

Lycopus rubellus

Panicum hemitomon

Panicum virgatum

Paspalum distichum

Polygonum sp.

Pontederia cordata

Sagittaria latifolia

Scirpus cyperinus

Sparganium americanum

Typha domingensis

Typha latifolia

\section{Common name}

Water pennywort

Rush

Rush

Soft rush

Rush

Rice cutgrass

Water horehound

Panic grass

Switchgrass

Knotgrass

Smartweed

Pickerelweed

Arrowhead

Bulrush

Bur reed

Cattail

Cattail
Quantity

planted

$<100$

$<100$

$<100$

$>2000$

$<100$

$>2000$

$<1000$

$>2000$

10 lbs

$<1000$

$<2000$

$<1000$

2000

$<2000$

$<100$

$<1000$

$>2000$

Upper emergent/shrub zone

Acer rubrum

Red maple

$>2000$

Buttonbush

$>2000$

Climbing hempweed

$<100$

Blackgum

$>2000$

Nyssa sylvatica

Black willow

$>2000$

Salix nigra

Cypress 
Along some areas of shoreline individuals of Nelumbo lutea were spaced nine meters (30 ft) apart because of limited quantities. Vallisneria americana, a submersed species, was planted by weighting a plant and a fertilizer tablet in a cheesecloth bag and tossing the bags from a boat.

Once plants were introduced into L-Lake it was expected that they would reproduce and fill unoccupied areas. Plant reproduction could occur sexually through seed production and dispersal, or asexually by the separation of a plant into a fragment capable of reforming a whole plant or by spreading from the roots. Asexual reproduction is also called vegetative reproduction and occurs commonly.

The presence of the human pathogenic amoeba, Naegleria fowleri in L-Lake made working in water hazardous. This amoeba may cause the fatal disease Primary Amoebic Meningoencephalitis which results if the amoeba migrates up the nasal passages, through the olfactory nerve, and into the brain. Therefore, floating-leaved and submersed species could not be transplanted safely to water more than knee deep. Only the shallow areas of the submersed/floating-leaved zone were planted.

\section{Vegetation Sampling}

Permanent belt transects, $2 \mathrm{~m}$ wide, were established in a stratified random pattern, perpendicular to the shore of L-Lake. Fifty-four transects were sampled, thirty-two in planted areas and twenty-two in unplanted ones (Fig. 2). Species presence was recorded and percent cover was estimated in paired one square meter sample plots beginning at an elevation approximateiy $30 \mathrm{~cm}(1 \mathrm{i})$ above the waterline and continuing at one meter intervals to a water depth of one meter. Trees greater than $2.5 \mathrm{~cm}$ (1 in) diameter at the 


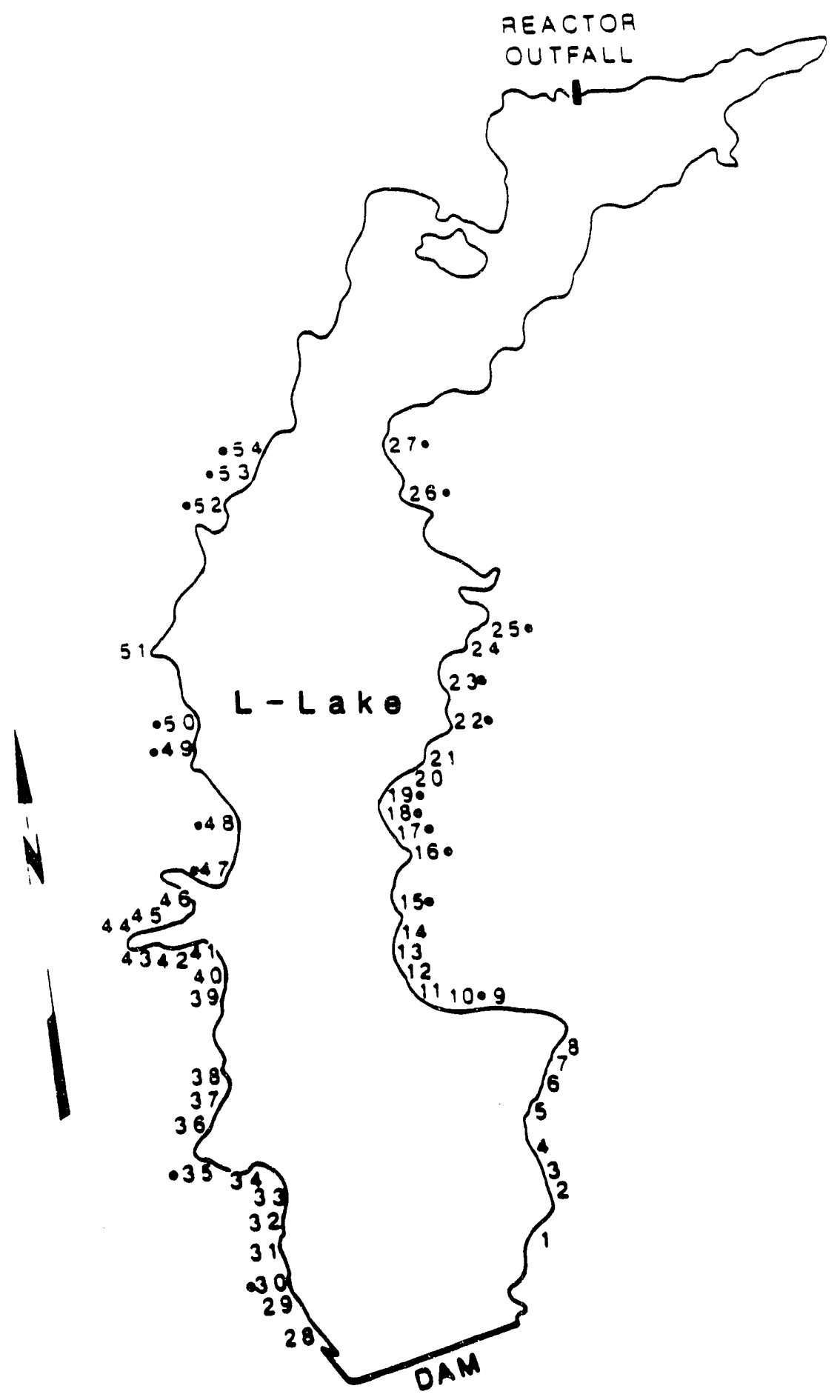

FIGURE 2. Location of permanent sample transects. Transects marked with a dot $(\cdot)$ are located in unplanted areas. 
base were not sampled because the sampling design employed here was appropriate only for herbaceous plants and woody seedlings. Since the wetland vegetation in L-Lake was in an early stage of development, there were many sample plots with no plants. This absence of vegetation was recorded and was especially common in the submersed/floating. leaved zone.

Cover was estimated as the percentage of ground surface covered by vegetation when looking down from above the vegetation. Cover represents the vertical projection of plant parts (leaves and stems) onto the ground (Bonham 1989) and approximates the area over which a species exerts influence. Cover for a species may range from 1 tc $100 \%$ in each plot. Because of overlap, total cover for all species in any plot may be greater than $100 \%$. Small individuals and seedlings were assigned a cover value of one percent.

Taxonomonic nomenclature follows that of Radford, Ahles and Bell (1968). In some cases, the lack of flowers and fruits prevented identification of a plant to the species level. Since Panicum hemitomon and Sacciolepis striata share the same habitat and are difficult to differentiate vegetatively, these grasses were combined into one group called Panicum/Sacciolepis.

The elevation of each transect was surveyed at one meter intervals from approximately $40 \mathrm{~cm}$ above the waterline to one meter water depth. These elevational data, based upon the normal high water mark, were used to demarcate the three vegetation zones. The normal high water mark was determined by measuring the elevation of water marks on rocks and on a pier. 


\section{Data Analysis}

Measurements of how often a species occurred (absolute frequency) and how much area it influenced (absolute cover) were obtained during sampling. Absolute frequency and cover were converted to relative frequency and relative cover and expressed as a percentage. The relative frequency of a species is the absolute frequency of that species divided by the sum of the absolute frequencies of all species. Likewise, the relative cover of a species is the ratic of its coverage to the total coverage for all species.

Both absolute and relative values are helpful in interpreting plant community data. For example, if four species were found in each of ten sample plots, then the absolute frequency for each species is $100 \%$, whereas the relative frequency for each species is $25 \%$. The first value expresses the probability of occurrence in a sample plot, and the second expresses the probability of occurrence among the species sampled. Cover and frequency for a species may occur in various combinations. For example, a species may occur in many plots but have low cover, or in few plots and have high cover. Integrating frequency and cover is achieved by summing the values for relative frequency and relative cover. This sum is commonly called an importance value and, in the results presented here, has a maximum value of 200. A species with a high importance value is not necessarily an ecologically important one, but it is notable given the sample data.

Importance values were used both to compare vegetation in the planted areas among the three years of study and to compare vegetation structure and development between planted and unpianted areas. This latter comparison was made between categories of species such as submersed, floating-leaved, emergent, terrestrial or shrub. Wetland species 
which became established naturally were assigned to the appropriate category using Reed (1986). A terrestrial species was defined as an herbaceous plant not listed in Reed (1986). Appendix B provides the number sampled and coverage for all species by zone in both planted and unplanted areas of L-Lake.

\section{Vegetation Sampling at PAR Pond}

Wetland vegetation of PAR Pond has become established naturally since the lake was constructed in 1958 . There are well developed zones of vegetation that served as the model for the vegetation structure of L-Lake. Data on the structure and composition of the emergent vegetation were collected in 1985 using belt transects one meter wide (Harrison, unpublished); thirty-two transects were sampled, sixteen in the north arm and 16 in the cold arm. Species presence was noted and species cover was estimated in one square meter sample plots at one meter intervals along these transects from the waterline to a point in the water where the emergent vegetation ended. The focus of the PAR PCnd study was on emergent vegetation, therefore much of the submersed/floatingleaved zone was neglected. Since water depth was measured the vegetation data was analyzed in the same way as the L-Lake data. This allowed comparisons of the vegetation between L-Lake and PAR Pond to be made.

\section{RESULTS and DISCUSSION}

\section{Submersed and Floating-leaved Vegetation}

The shoreline between $30 \mathrm{~cm}(1 \mathrm{ft})$ and $100 \mathrm{~cm}(3.3 \mathrm{ft})$ water depth defines this zone of submersed and floating-leaved vegetation. Nine species of submersed and floatingleaved plants were planted (Table 1). A total of 940 plots in planted areas and 786 in 
unplanted areas were sampled each year (Table 2).

\section{Transplant Survival}

Of the nine species planted, American lotus (Nelumbo lutea), a floating-leaved species, and water celery (Vallisneria americana), a submersed plant, survived in 1989. Deep water and the presence of the pathogenic amoeba, $N$. fowleri, made this an unsafe zone to plant and sample. Wave action, combined with the initial planting of fewer than 100 individuals of some species (Table 1), apparently made establishment of some species difficult.

Few studies have addressed the establishment of transplanted submersed and floatingleaved species. Kollar (1985) had no success transplanting the submersed species Potamogeton pectinatus and P. perfoliatus in the Chesapeake Bay. He suggested that high turbidity and algal epiphytes may have prevented these species from becoming established. L-Lake has high turbidity and algal blooms during the summer that may have prevented successful transplantation of some species. Kollar (1985) successfully transplanted $V$. americana in the Chesapeake Bay, and it is also becoming well established in L-Lake. This species and $N$. lutea are colonizing unoccupied areas in the submersed zone of LLake quickly (Fig. 3).

Changes from 1987 to 1989 in Planted Areas

Colonization is occurring rapidly in this zone. In $1987,95 \%$ of the plots sampled had no vegetation present. By 1989 , the percentage of empty plots had declined to $62 \%$ (Table 2). Much of this reduction in the number of empty plots was due to expansion of $V$. americana and $N$. lutea. Concomitant with the colonization of empty plots has been a 


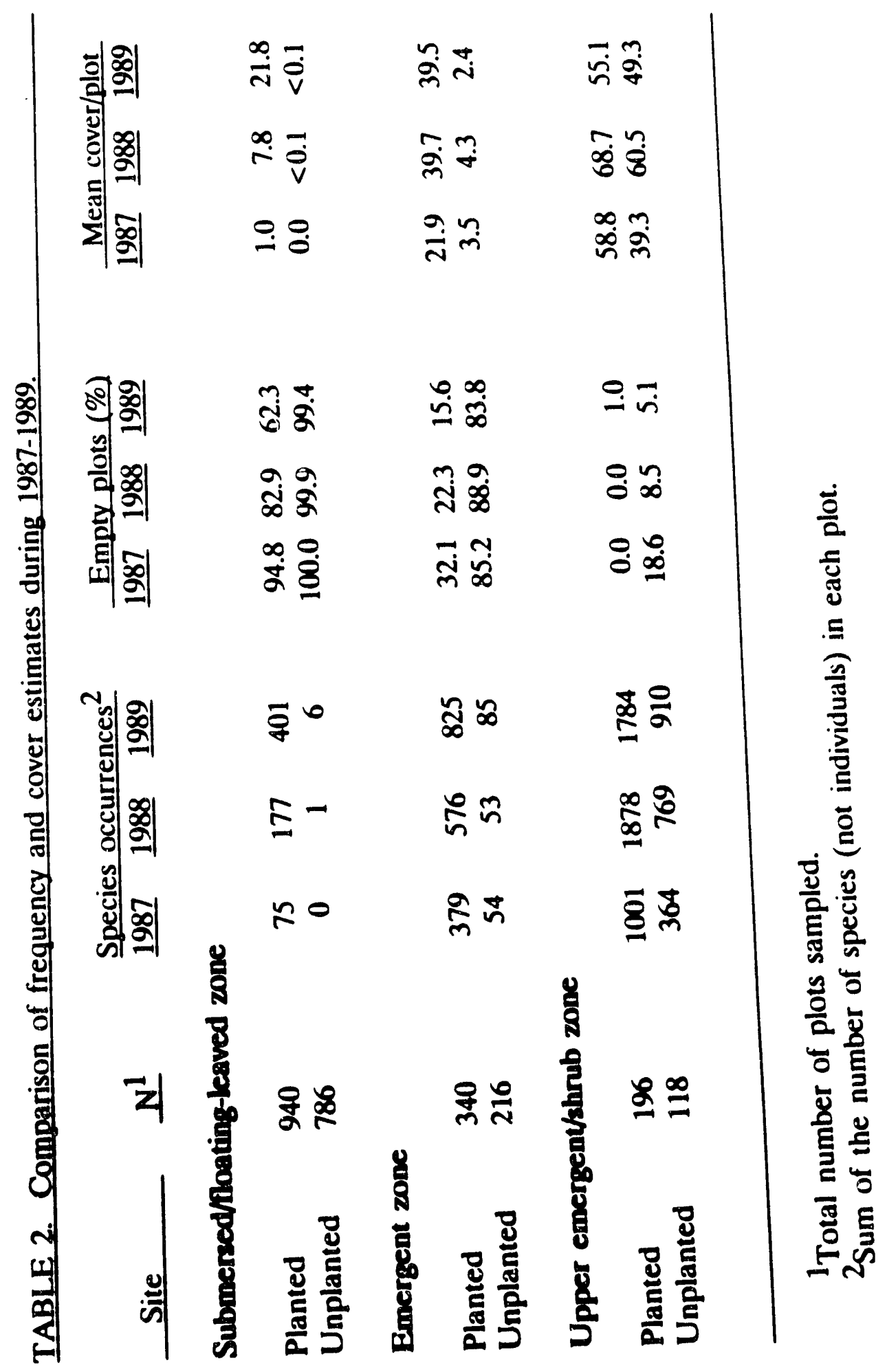



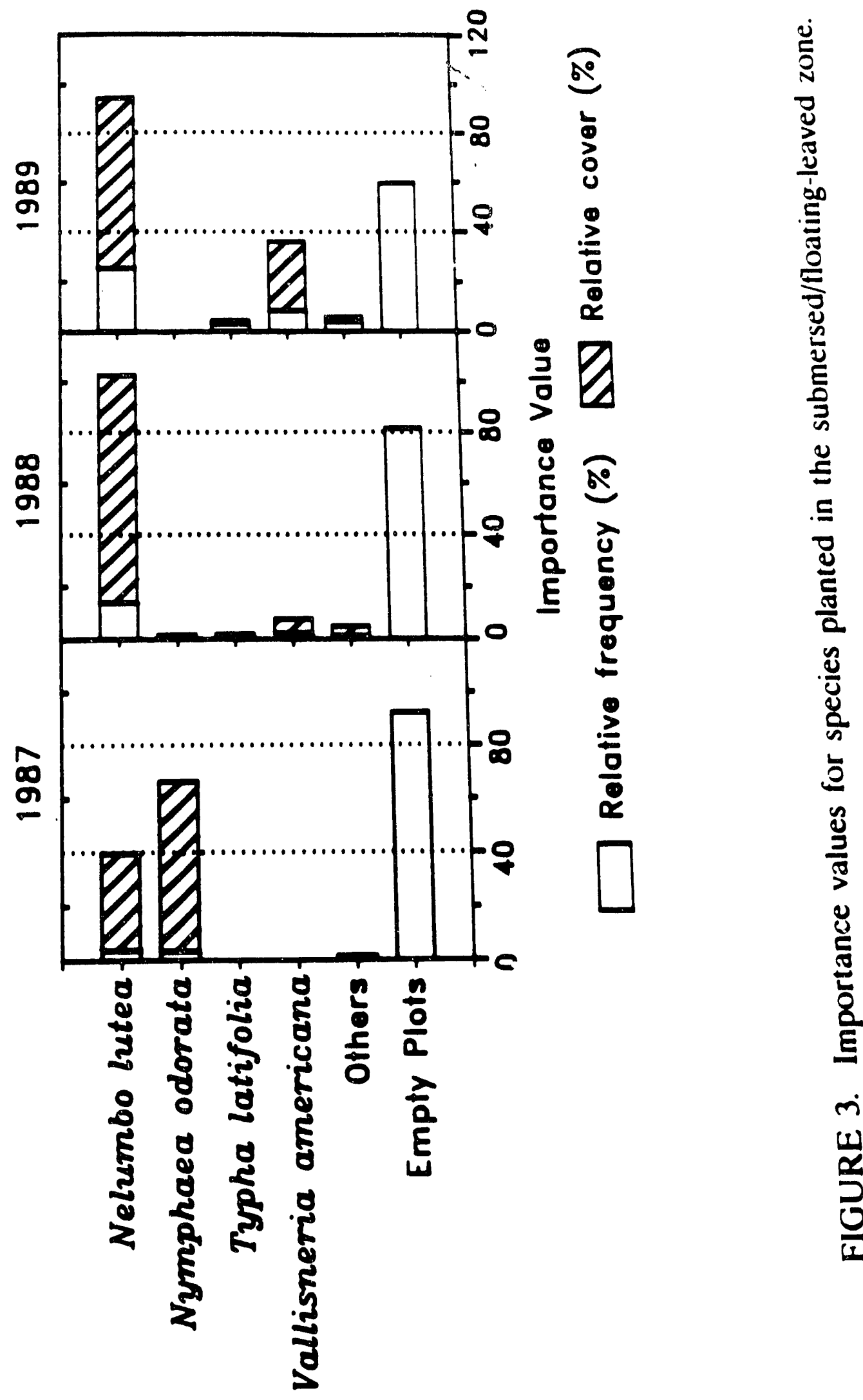

$\frac{2}{2}$ 
substantial increase in plant cover. In 1987 mean cover per plot was $1 \%$, however, this increased to $22 \%$ by 1989 (Table 2). Cattails (Typha latifolia) are expanding into this zone from the emergent zone (Fig 3).

Vallisneria americana is present on both the east and west shores of L-Lake and is found on clay and sand substrates. When transplanted, it soon drops its leaves and exists as a tuber in the sediment. This transplant response probably explains its apparent absence in 1987 (Fig. 3). In 1989, V. americana was present in $8.8 \%$ of the plots sampled and its frequency may have been underestimated due to lake turbidity and water depths of nearly one meter. Only vegetative reproduction has been observed.

The establishment of Vallisneria americana (a major winter food for waterfowl; Jones and Drobney 1986) suggests that L-Lake may become a feeding area for wintering waterfowl. Although it is a common plant nationally, it is uncommon in South Carolina. On the Savannah River Site, it is found only in PAR Pond and L-Lake (Knox and Sharitz 1990).

Nelumbo lutea is also a quick colonizer. In 1987 , it occurred in only $3.9 \%$ of sampled plots, but by 1989 its absolute frequency had increased to 26.7\%. Radial growth of 14 meters $(45 \mathrm{ft})$ in one growing season has been reported for j)atches in Tennessee Valley Authority reservoirs (Hay and Penfound 1944). Although radial growth of N. lutea has not been measured in L-Lake it has occurred very rapidly. It is reproducing vegetatively and is present only along portions of the eastern shoreline. It did not become established along the western shoreline. Although it does produce seeds, there has been no evidence of seedling establishment. 
During 1987, the white water lily, Nymphaea odorata, shared dominance with $N$. lutea (Fig. 3). In 1989, however, only one $N$. odorata individual was found in an unsampled and protected area in the northwestern portion of the lake. In PAR Pond, $N$. odorata and water shield (Brasenia schreberi) occur in protected areas such as coves. Water flow from reactor discharge may prevent these species from occurring near discharge points (Grace 1984). Thus the extirpation of $N$. odorata from planted areas in L-Lake may have been caused by wave action which uprooted or damaged the plants.

\section{Comparison Between Planted and Unplanted Areas}

No submersed or floating-leaved vegetation was present in unplanted sites in 1989, thus planting appears essential in promoting the establishment of this zone (Fig 4). Four years after lake construction was completed, nearly all plots in unplanted areas remained unvegetated (Table 2). Five plots contained cattail ( $T$. latifolia) or water pennywort (Hydrocotyle umbellata). These two emergents accounted for $100 \%$ of the relative cover in the unplanted areas (Fig. 4).

Comparison with Submersed/Floating-leaved Vegetation at PAR Pond

There are few similarities beween the vegetation of this zone in L-Lake with the vegetation in PAR Pond. Nelumbo lutea is common in both reservoirs (Fig. 5). PAR Pond has a greater species diversity, however water pennywort (Bacopa caroliniana), spike rush (Eleocharis quadrangulata), pickerelweed (Pontederia cordata) and cattail (Typha latifolia) are emergent species (Fig. 5). It will take some time before these species, present in the emergent zone of L-Lake, expand into the submersed/floating-leaved zone. Although present in PAR Pond, $V$. americana was not sampled. 


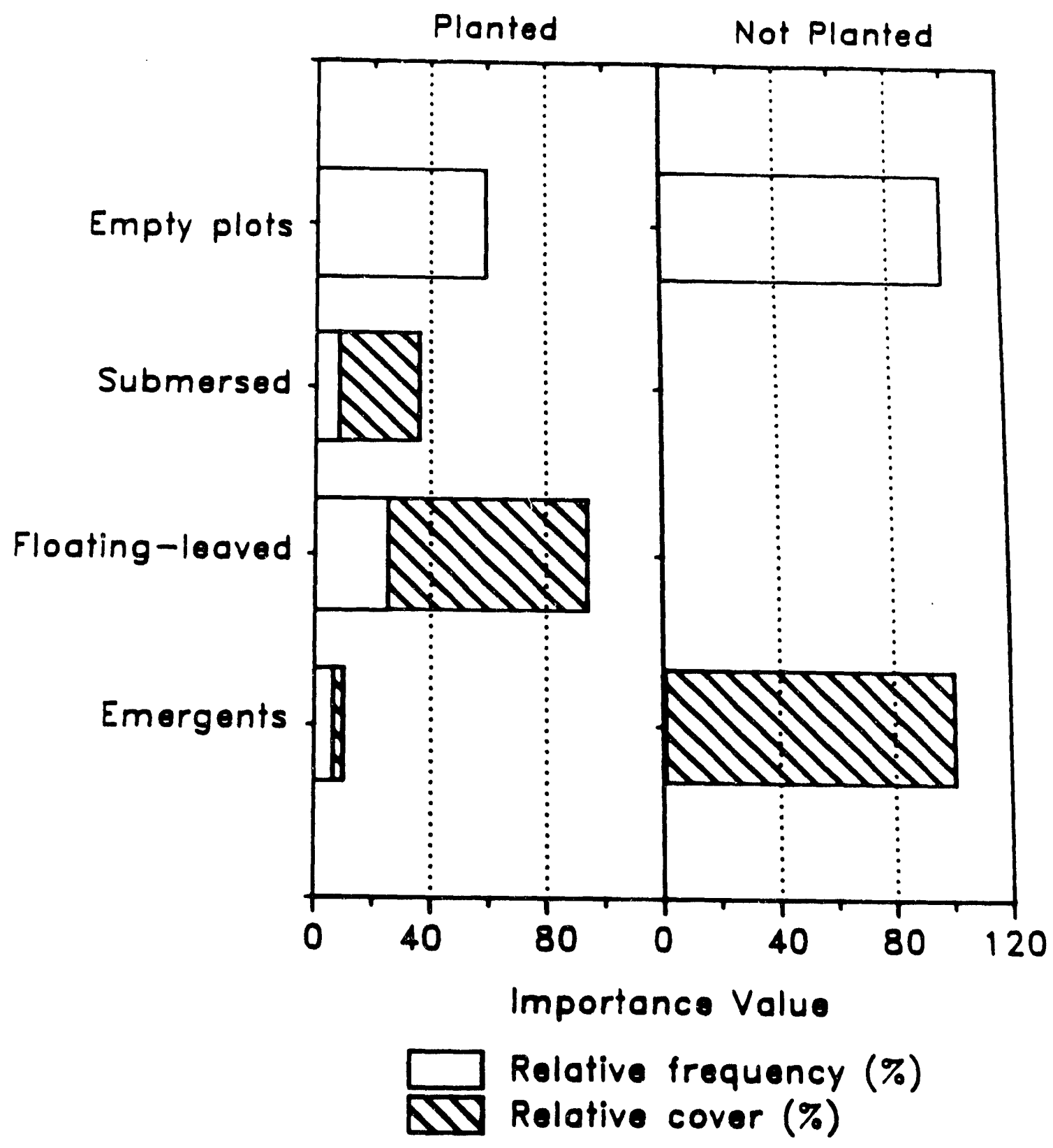

FIGURE 4. A comparison of vegetation between planted and unplanted areas of L-Lake in the submersed/floating-leaved zone. 


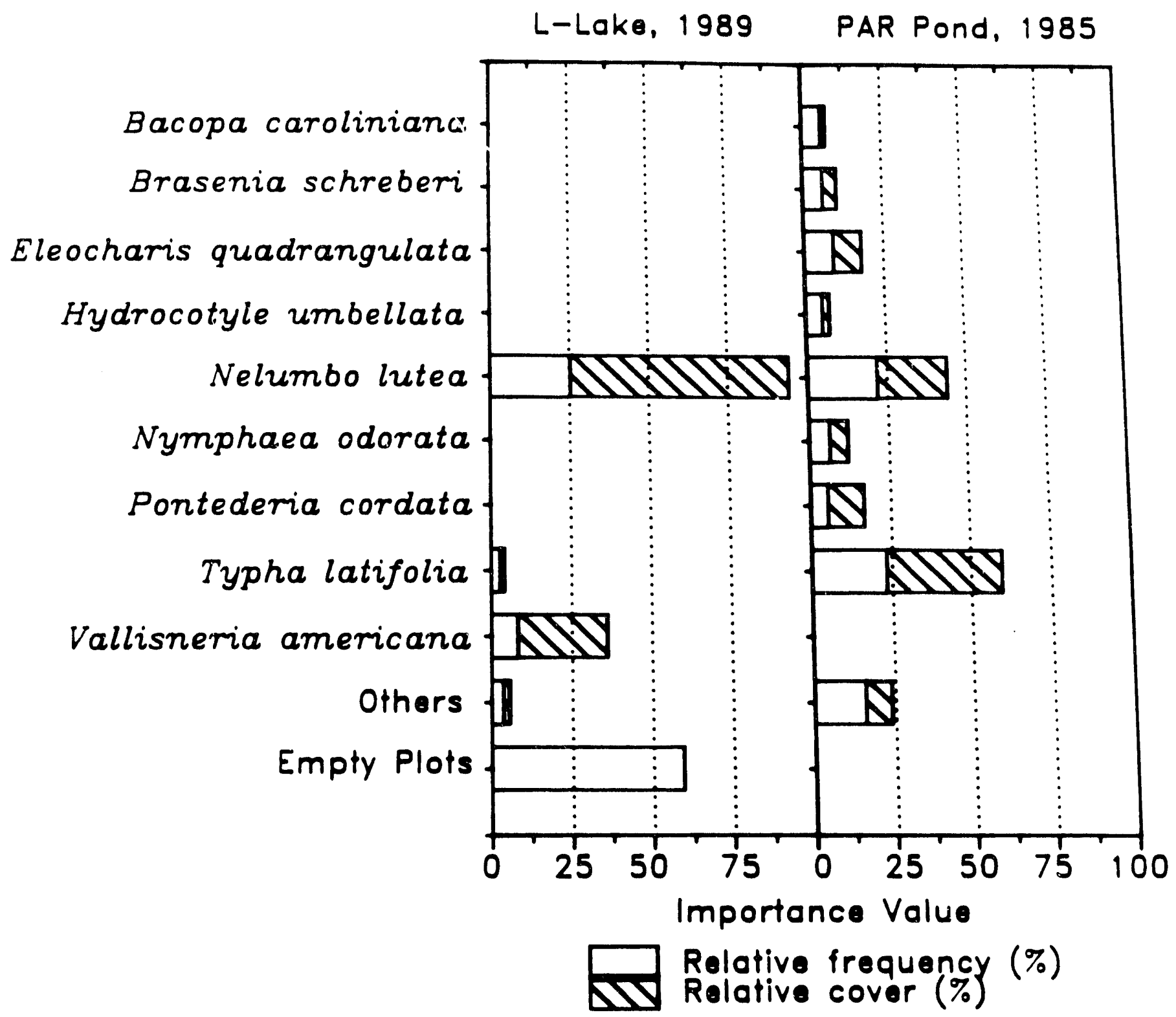

FIGURE 5. A comparison of vegetation between L-Lake and PAR Pond in the submersed/floating-leaved zone. 


\section{Emergent Vegetation}

This zone lies between the waterline and $30 \mathrm{~cm}(1 \mathrm{ft})$ of water. Approximately 30 species were planted (Table 1). A total of 340 plots in planted areas and 216 plots in unplanted areas were sampled (Table 2).

\section{Transplant Survival}

Most species planted in this zone were still present in 1989. Spikerushes (Eleocharis equisetoides and $E$. quadrangulata), water pennywort (H. umbellata), soft rush (Juncus effiusus), grasses, smartweeds (Polygonum persicaria and $P$. hydropiperoides) and cattail (T. latifolia) were the most common emergents present in 1989 (Fig. 6).

Emergent species that were intially planted but not recorded in any subsequent sampling year include Dulichium arundinaceum, Glyceria striata, Juncus acuminatus, J. brachycarpus, J. diffusisimus and Typha domingensis. Two of these species, D. arundinaceum and $T$. domingensis, have been observed along areas of shoreline outside the sample transects. The Juncus spp. may have failed to survive or may have been missed 1 in the samples because of problems with identification.

Changes from 1987 to 1989 in Planted Areas

The number of species occurences increased from 379 in 1987 to 825 in 1989. Accompanying this increase has been a decrease in the number of empty plots. In 1987, $32 \%$ of the 340 plots sampled were empty, but by 1989 the percentage declined to $16 \%$. Mean cover per plot increased from $22 \%$ from 1987 to $40 \%$ in 1988 and remained similar for 1989 (Table 2). Noteworthy changes for emergent species included a gradual increase in relative frequency of Eleocharis spp. and $T$. latifolia, a large increase of $H$. umbellata 


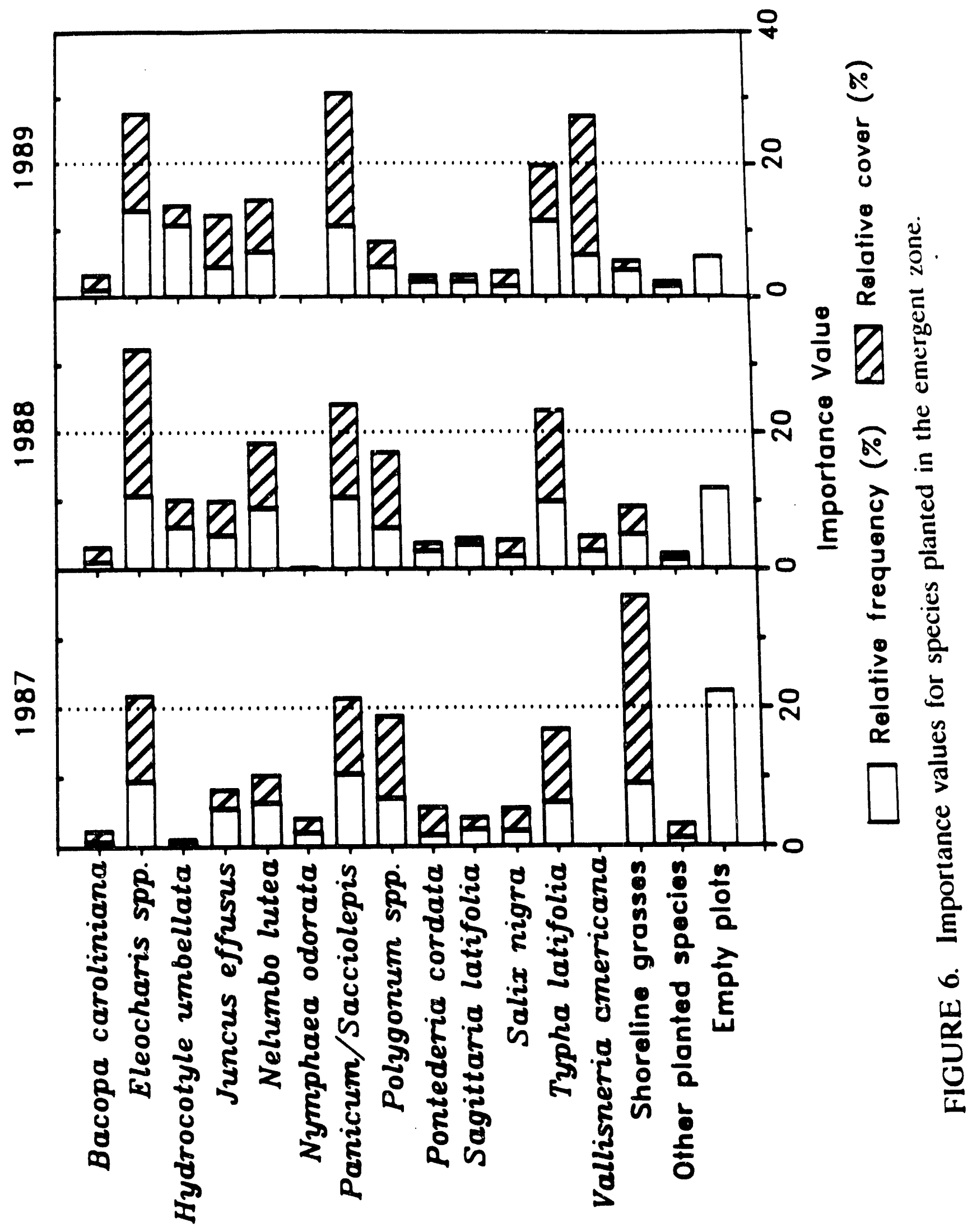


and $V$. americana and a major decrease in relative frequency and cover of the shoreline grasses.

Water depth was the major factor separating two distinct groups of grasses. Forming one group were Panicum hemitomon, a planted species, and Sacciolepis striata, an unplanted species. Both species grew outward from the shore into shallow water. Because of similar growth patterns and the difficulty in distinguishing them, these species were considered as one group. All other planted grass species comprise the second group called shoreline grasses. They were growing at or near the shoreline and not out into the water. The lack of flowers prevented identification of many shoreline grasses to species.

Changes in grass composition between 1987 and 1989 include a large decrease in relative frequency and relative cover of the shoreline grasses and a gradual increase in these parameters for the Panicum/Sacciolepis group (Fig. 6). In 1987, relative cover of shoreline grasses was $27 \%$, but by 1989 had decreased to $1.4 \%$. Most of this decrease in relative cover resulted from a decline in the absolute cover from $20.2 \mathrm{~m}^{2}$ in 1987 to $1.9 \mathrm{~m}^{2}$ in 1989 . A $46 \mathrm{~cm}(1.5 \mathrm{ft})$ drop in the water level of L-Lake during summer 1987 may have aided the establishment of shoreline grasses. The subsequent decrease in frequency and coverage for shoreline grasses was probably due to lake levels returning to normal.

Most emergent species are reproducing vegetatively, however reproduction by seed was observed of $\boldsymbol{H}$. umbellata, T. latifolia, J. effusus and Pontederia cordata. During 1987, blocks of $P$. cordata occurred only where the species was planted. However, by 1989 , all of these blocks had been destroyed by beavers or pigs. In 1989, individual plants, not 
blocks, of $P$. cordata had become established along both east and west shores; one plant was found in an unplanted area.

Cattail ( $\mathcal{T}$. lctifolia) was present in the lake before transplanting began, however most of the individuals sampled in planted areas were transplants. Cattails transplanted in winter did not survive as well as those transplanted during spring after the emergence of new growirs. Ristich et al. (1976) found significant differences in survival of $T$. angustifolia planted at different times, with the highest survival rates occurring for individuals transplanted druing late spring (May-June). Observations of $T$. latifolia at L-Lake are consisteni with his results.

In 1987, cattail was present in $9 \%$ of the 340 plots sampled. By 1989, its absolute frequency had increased to $29 \%$. Although cattail seedlings have been observed, most of its expansion was due to vegetative reproduction. It has spread both laterally along the shore and into the deeper water of the submersed and floating-leaved zone.

Nelumbc lutea and $V$. americana were also important components of this zone. These two species have gown into the emergent zone from the submersed and floating-leaved zone.

\section{Comparison Between Planted and Unplanted Areas}

Emergent vegetation is becoming established slowly in unplanted shoreline areas (Fig 7). Alligator weed (Altemanthera philoxeroides), $H$. umbellata and $T$. latifolia were the only emergent species in unplanted areas with absolute frequencies greater than $5 \%$ in 1989. The number of empty plots in unplanted areas has remained relatively constant since 1987 (Table 2). In 1989, 84\% of the 216 plots sampled had no vegetation present. 


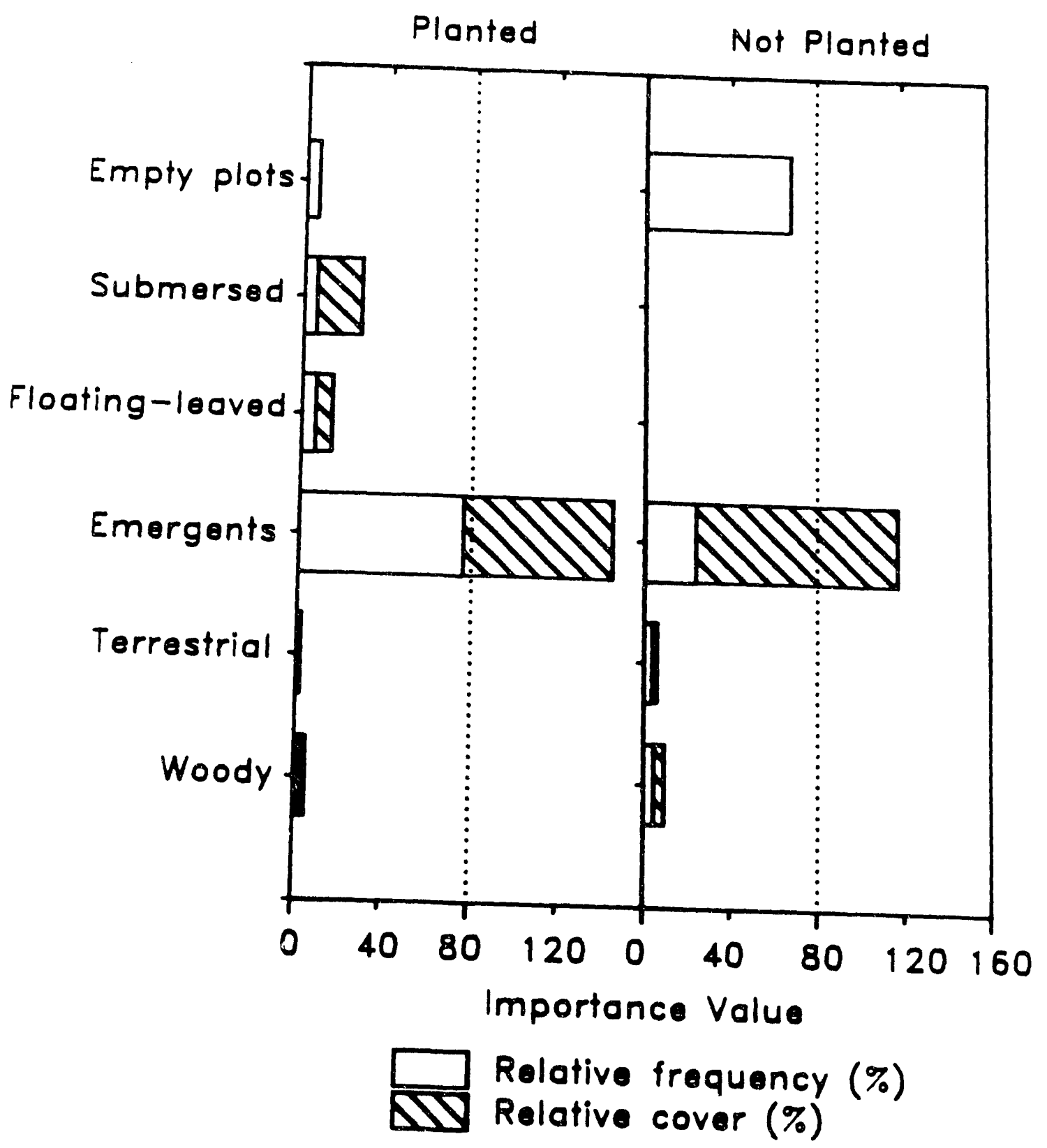

FIGURE 7. A comparison of vegetation between planted and unplanted areas of L-Lake in the emergent zone. 
No submersed or floating-leaved vegetation was present in unplanted areas.

Planting of emergent species greatly promoted the establishment of this vegetation type. Most plots in the unplanted areas remained empty or had low species diversity. In planted areas, $15.6 \%$ of the plots remained empty since planting of vegetation in 1987. Comparison with Emergent Vegetation at PAR Pond

The Panicum/Sacciolepis grasses were the most important component of the vegetation in both sites (Fig. 8). Vallesneria americana was important in L-Lake but was not sampled in PAR Pond. Its absence from PAR Pond may be because it is a submersed species and the PAR Pond sampling emphasized emergent species. Species not sampled at L-Lake but present in PAR Pond included Erianthus giganteus and Hypericum spp. Both species were present outside the sample transects at L-Lake but in very low numbers. Scirpus cyperinus and Lycopus spp. occur more commonly above the water line at L-Lake.

\section{Upper Emergent/Shrub Vegetation}

The portion of shore from the waterline to approximately $30 \mathrm{~cm}(1 \mathrm{ft})$ above the water line delineates this zone. This area represents a portion of the shrub zone defined by Whigham et al (1985) as occurring between the water line and $0.9 \mathrm{~m}(3 \mathrm{ft})$ above the water line. The results presented here focus on herbs and shrubs, since trees greater than $2.5 \mathrm{~cm}$ diameter at the base were not sampled. A total of 196 plots was sampled in planted areas and 118 plots in unplanted areas (Table 2). The distinction between planted and unplanted areas is not useful for shrubs in this zone because shrubs were planted along most of the southern two-thirds of the lake. The distinction is accurate, however, for the herbaceous transplants in the other two zones. 
L-Lake, 1989 PAR Pond, 1985

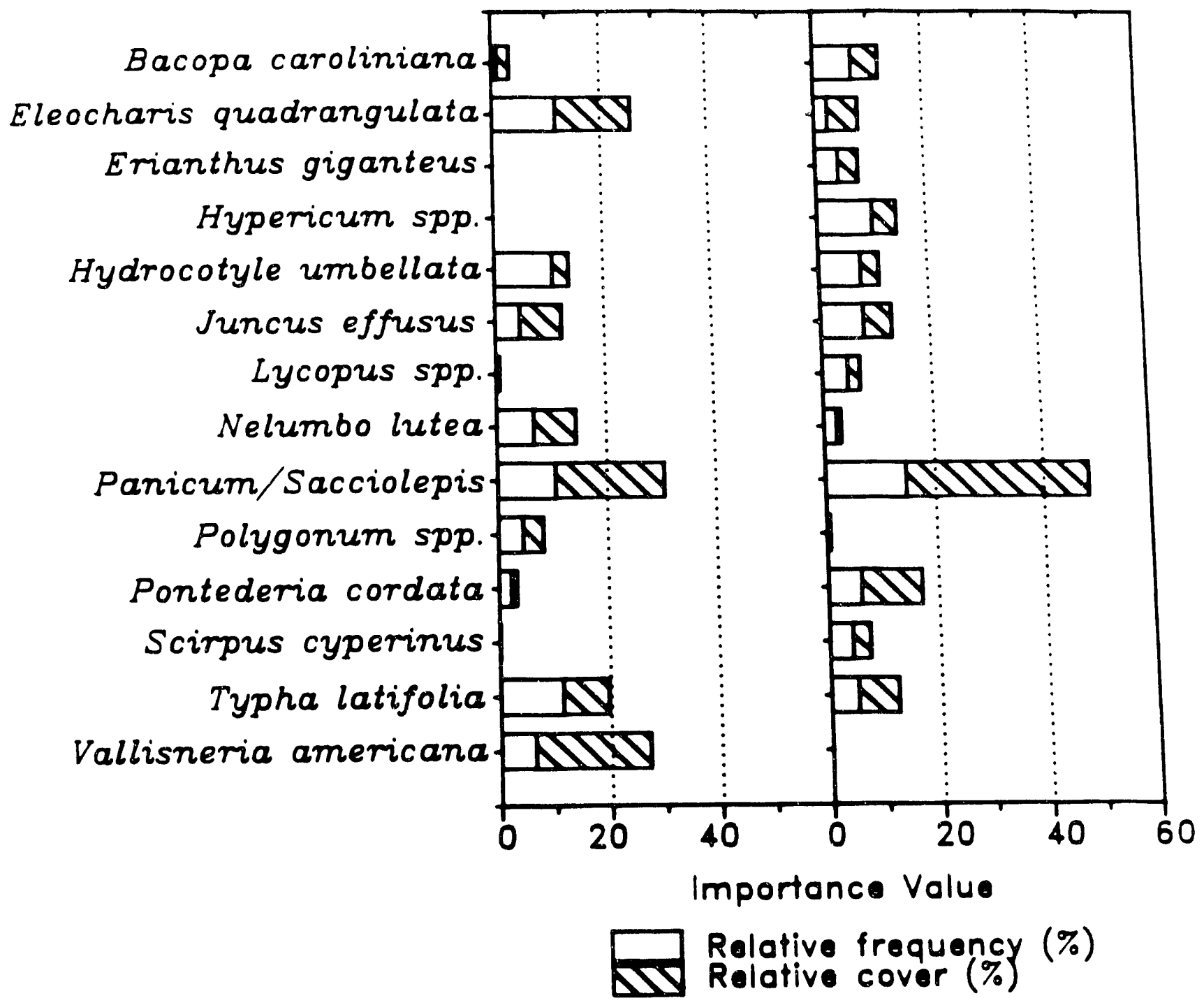

FIGURE 8. A comparison of vegetation between L-Lake and PAR Pond in the emergent zone. 


\section{Transplant $\underline{\text { Survival }}$}

All species planted in 1987 were present in 1989. The emergents J. effusus, Polygonum spp. S. latifolia, T. latifolia, the shoreline grasses and Panicum/Sacciolepis were also important components of this zone (Fig. 9).

Changes from 1987 to 1989 in Planted Areas

This zone was sufficiently vegetated with terrestrial species that the proportion of barren plots was always very low (Table 2). Mean cover per plot increased from $59 \%$ in 1987 to $69 \%$ in 1988 and then decreased to $55 \%$ in 1989 (Table 2). Damage to vegetation by feral pigs was noted in 1989 , but additional unknown factors may have contributed to the decrease in cover.

The most striking change was a large decrease in relative frequency and relative cover of the shoreline grasses. Probable explanations for these decreases are the same as those for the decline in shoreline grasses in the emergent zone. The Panicum/ Sacciolepis group had a gradual increase in cover and frequency. Most individuals of cattail ( $T$. latifolia) planted in this zone experienced shading by willow ( $S$. nigra) and died. An overall decrease in relative frequency and relative cover of cattail has occurred (Fig. 9).

Willow was the dominant shrub. In many instances the $30-40 \mathrm{~cm}(1+\mathrm{ft})$ shoots planted in 1987 were 5-8 meters (16-26 ft) tall in 1989. Willow reproduction occurred vegetatively. Beavers have dispersed fragments of willow that became established as new individuals elsewhere. 


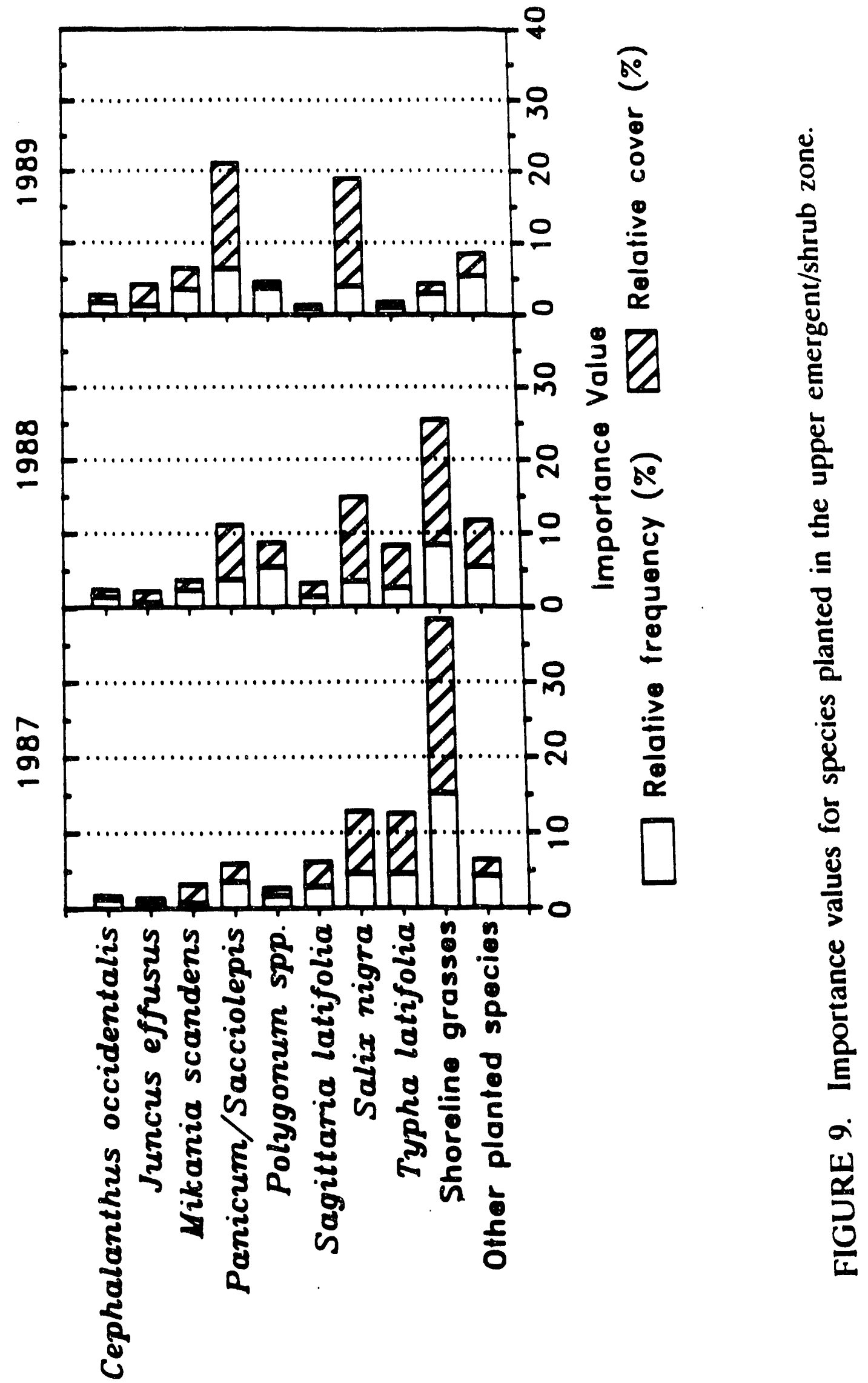


Buttonbush (Cephalanthus occidentalis) does not reproduce vegetatively as well as willow. Although its relative frequency and relative cover have increased since 1987, it was still one of the least important shrub species (Fig. 9).

\section{Comparison Between Planted and Unplanted Areas}

Facultative emergent and terrestrial species were the most important components of the unplanted areas (Fig. 10). The importance values of these groups are about the same in both planted and unplanted areas, however no J. effusus, Polygonum spp. nor Panicum/Sacciolepis were found in unplanted areas.

Willow was a dominant shrub in the unplanted areas. It occurred in $47 \%$ of the 118 plots sampled. In the planted areas it occurred in $36 \%$ of the 196 plots sampled.

\section{SUMMARY}

The submersed plant $V$. americana is found along both shores of L-Lake and is expanding rapidly. The floating-leaved plant $N$. lutea is only found along the southern half of the eastern shore, but it also is colonizing new areas quickly. No other species are components of the submersed/floating-leaved zone. This zone was difficult to establish resulting in a species diversity below expectations. The species present are, however, well established only where they were planted, and are reproducing vegetatively. In unplanted areas there is no submersed and floating-leaved vegetation. Attempts to establish this type of vegetation in other wetlands and lakes are not known.

The establishment of emergent vegetation in L-Lake exceeded expectations. Nearly all species planted in 1987 were present in 1989. Species diversity, in planted areas, is comparable to PAR Pond. Emergent vegetation is very slowly becoming established in 


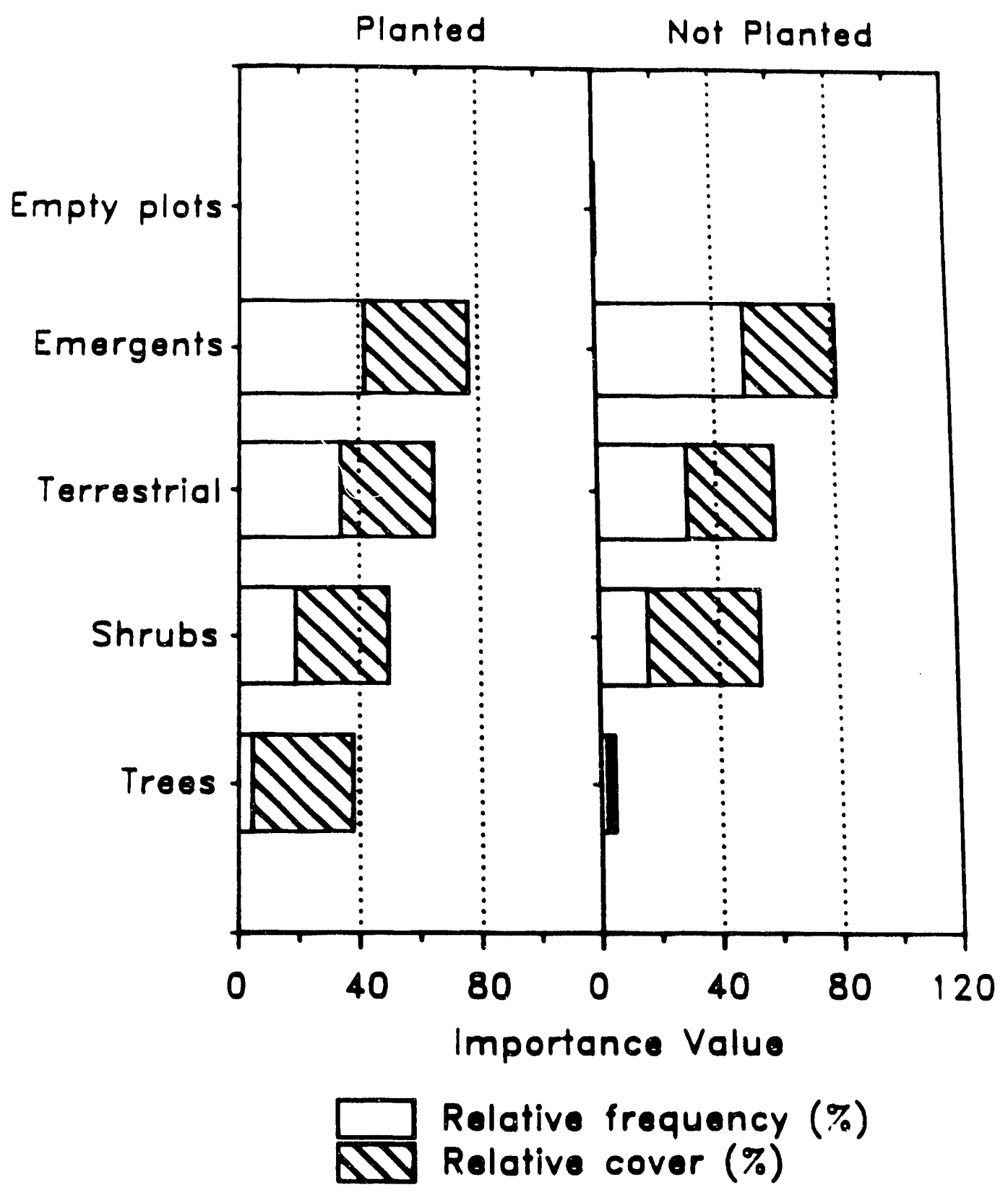

FIGURE 10. A comparison of vegetation between planted and unplanted areas of L-Lake in the upper emergent/shrub zone. 
comparable to PAR Pond. Emergent vegetation is very slowly becoming established in unplanted areas, and species diversity in these areas is low.

Willow is the dominate shrub in the upper emergent/shrub zone. Vegetation in this zone is a blend of emergent and terrestrial species. Woody vegetation is in an early growth stage.

\section{Acknowledgements}

Sally Landaal, Kevin Moorhead, Maria Vella, Gene Schupp, Rebbeca Sharitz and Kay Kirkman provided editorial advice. Aline Clement prepared the illustration (Figure 2) depicting plant zonation. I appreciate the help provided by these individuals. Most of all I am thankful for Priscilla Standford's help in vegetation sampling and data entry. 


\section{REFERENCES}

Bonham, Charles D. 1989. Measurements for Terrestrial Vegetation. John Wiley and Sons. $338 \mathrm{pp}$.

Grace, James. 1984. A survey of the wetland vegetation of PAR Pond. Unpublished. $39 \mathrm{pp}$.

Hall, T.F. and W.T. Penfound. 1944. The biology of American Lotus, Nelumbo lutea (Willd.) Pers. Am. Midl. Naturalist 31:744-758.

Jones, J.J. and R.D. Drobney. 1986. Winter feeding ecology of Scaup and Common Goldeneye in Michigan. J. Wildl. Manage. 50(3):446-452.

Knox, J. and R. Sharitz. 1990. Endangered, Threatened, and Rare Vascular Flora of the Savannah River Site. National Environmental Research Park Program, U.S. Department of Energy. SRO-NERP-20 147 pp.

Kollar, S.A. Jr. 1985. SAV reestablishment results-upper Chesapeake Bay. In: Coastal Zone '85: Proceedings of the Fourth Symposium on Coastal and Ocean Management. O.T. Magoon et al. editors. American Society of Civil Engineers, New York, N.Y. pp. 759-777.

Radford, A.E., H.E. Ahles and C.R. Bell. 1968. Manual of the Vascular Flora of the Carolinas. The University of North Carolina Press, Capel Hill. 1183 pp.

Reed, Porter B. Jr. 1986. Wetland Plants of the State of South Carolina 1986. U.S. Fish and Wildlife Service WELUT-86/W12.40. $37 \mathrm{pp}$.

Ristich, S.S., S.W. Fredrick and E.H. Buckley. 1976. Transplantation of Typha and the distribution of vegetation and algae in a reclaimed estuarine marsh. Bull. Torrey Botanical Club. 103(4):157-164.

Whigham, D., H. Allen, G. Davis, E. Garbisch, W. Kitchens, R. Sharitz, and L. Lee. 1985. A Management Plan for Establishment of Littoral/Wetland Vegetation on the Shoreline of L-Lake on the Savannah River Plant, South Carolina. 42 pp. 


\section{Appendix A: Maps of Shoreline Vegetation}

Topographic maps of portions of the shoreline of L-Lake were made by Besson and Pope in 1986. Six maps represent the southern one-half of the eastern shore and four depict the southern one-third of the western shore. Surveying stakes were placed at 200 foot inntervals along the shore at about the 190 foot contour. Stakes were numbered consecutively beginning at the dam and are symbolized by a filled triangle on the maps. A stake numbered E-12 marks the twelfth 200 foot interval from the dam along the eastern shore.

The topographic maps and the surveyors' stakes were used by Southern Tier Consuling (STC) in planting. The maps denote the locations of species planted and vegetation sample transects. Sample transects are denoted by numbers and lines perpendicular to the shore.

Codes are used to designate the locations of emergent species on the maps. The first two characters represent the genus, the last two represent the specific epithet. Submersed, floating-leaved, shrub and tree species are not coded. Codes are listed on the next page. 
Species codes used on the topographic maps:

\begin{tabular}{ll} 
COde & \multicolumn{1}{c}{ Species } \\
\cline { 2 - 2 } BACA & Bacopa caroliniana \\
CACO & Carex comosa \\
DUAR & Dulichium anundinaceum \\
ELEQ & Eleocharis equisetoides \\
ELQU & Eleocharis quadranulata \\
GLSP & Glyceria sp. \\
HYCA & Hydrochloa caroliniensis \\
JUAC & Juncus acuminatus \\
JUEF & Juncus effusus \\
LYRU & Lycopus rubellus \\
PAHE & Panicum hemitomon \\
PADI & Paskalum distichum \\
POCO & Pontederia cordata \\
POSP & Pohygonum spp. \\
SALA & Sagittaria latifolia \\
SCCY & Scirpus cyperinus \\
SPAM & Sparganium americanum \\
TYLA & Vypha latifolia \\
VAAM &
\end{tabular}




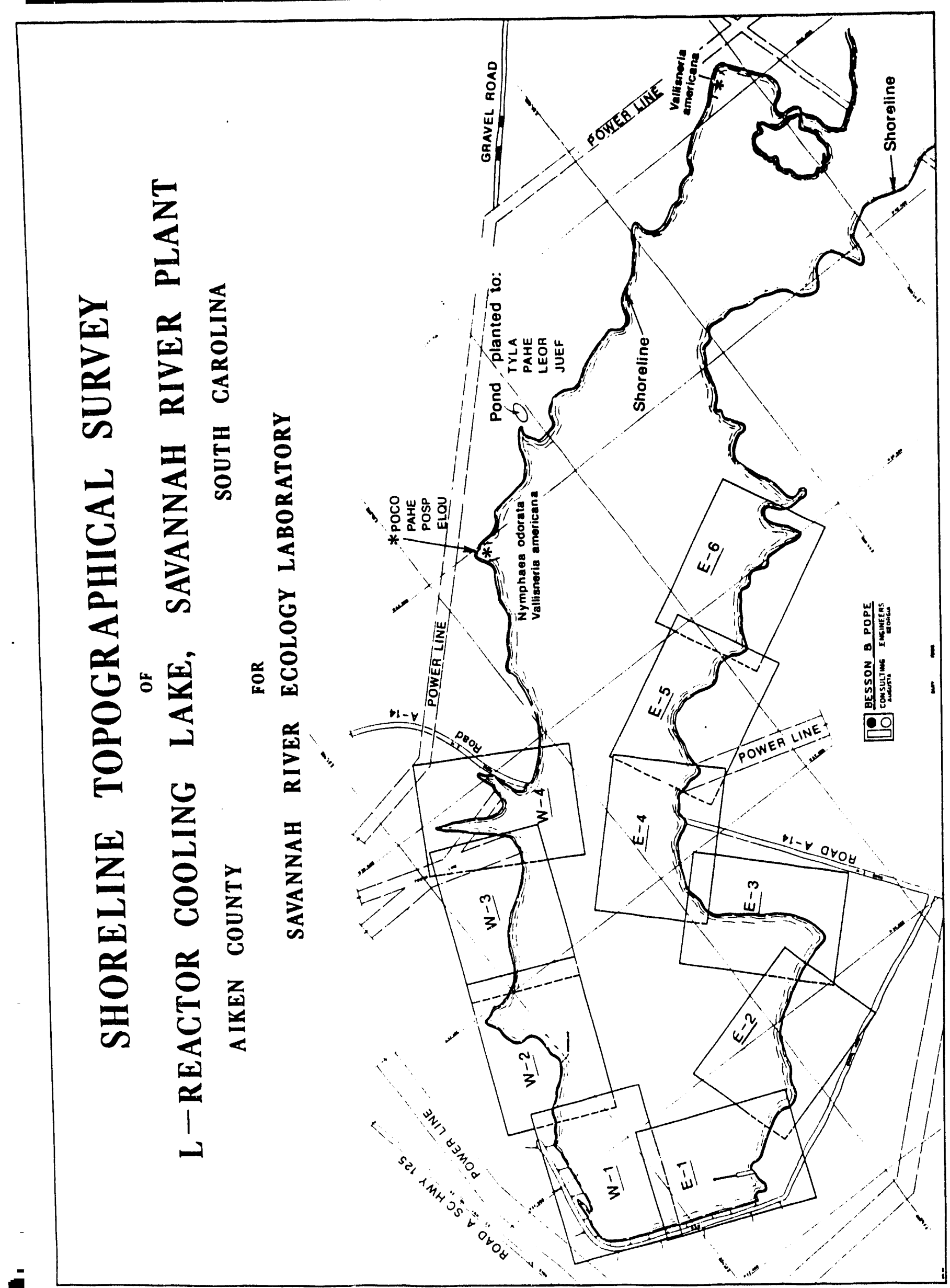




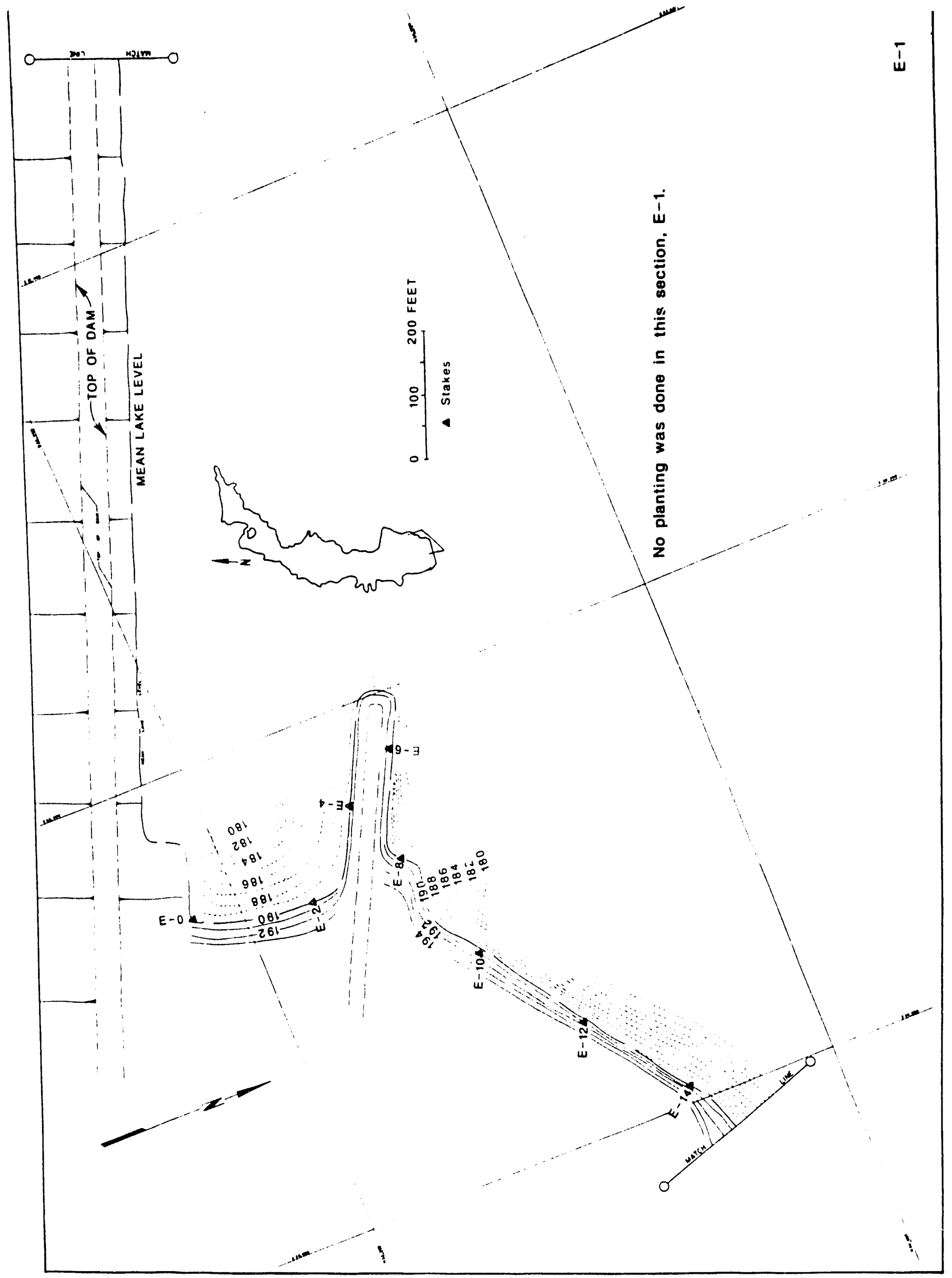




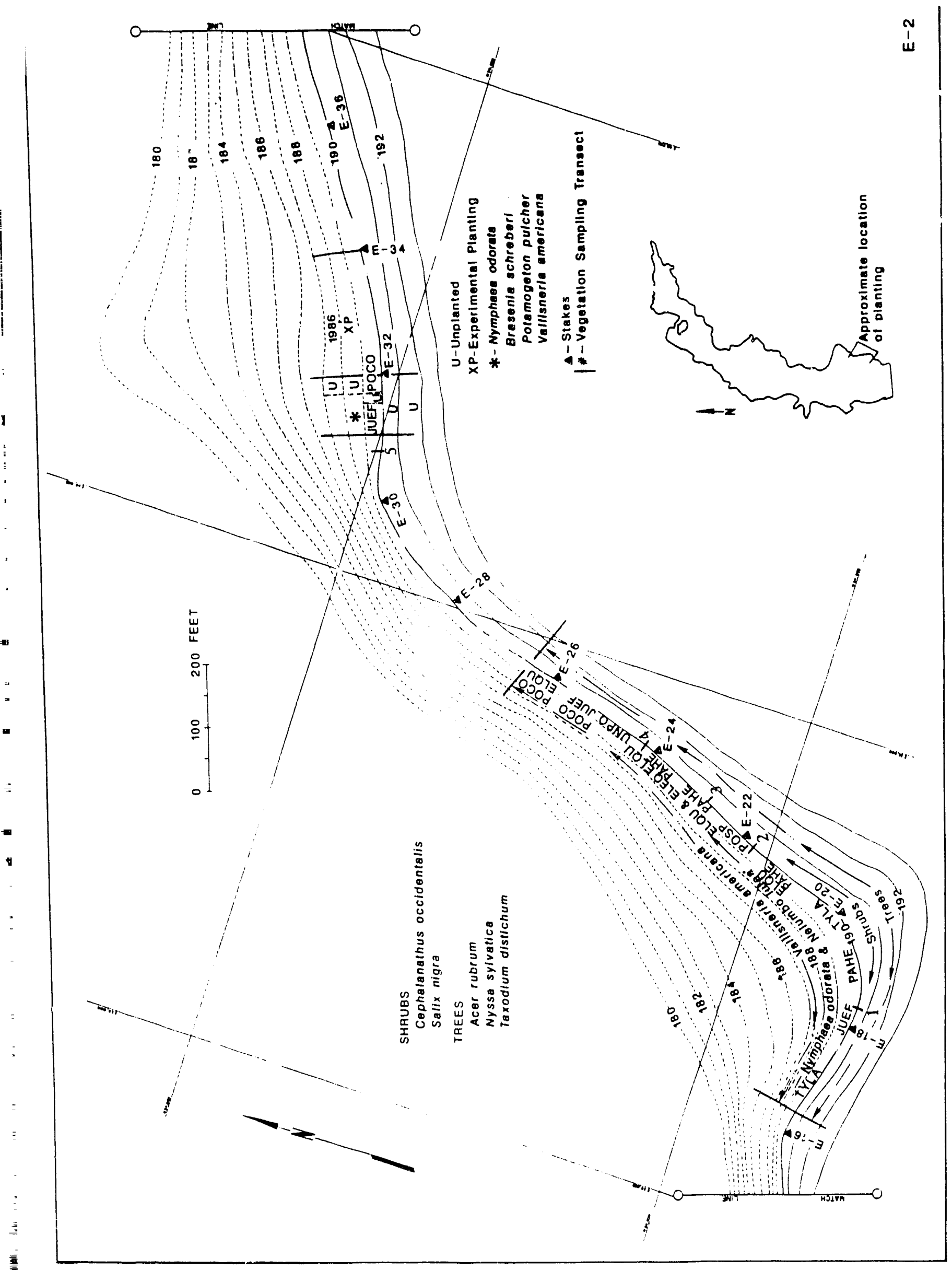




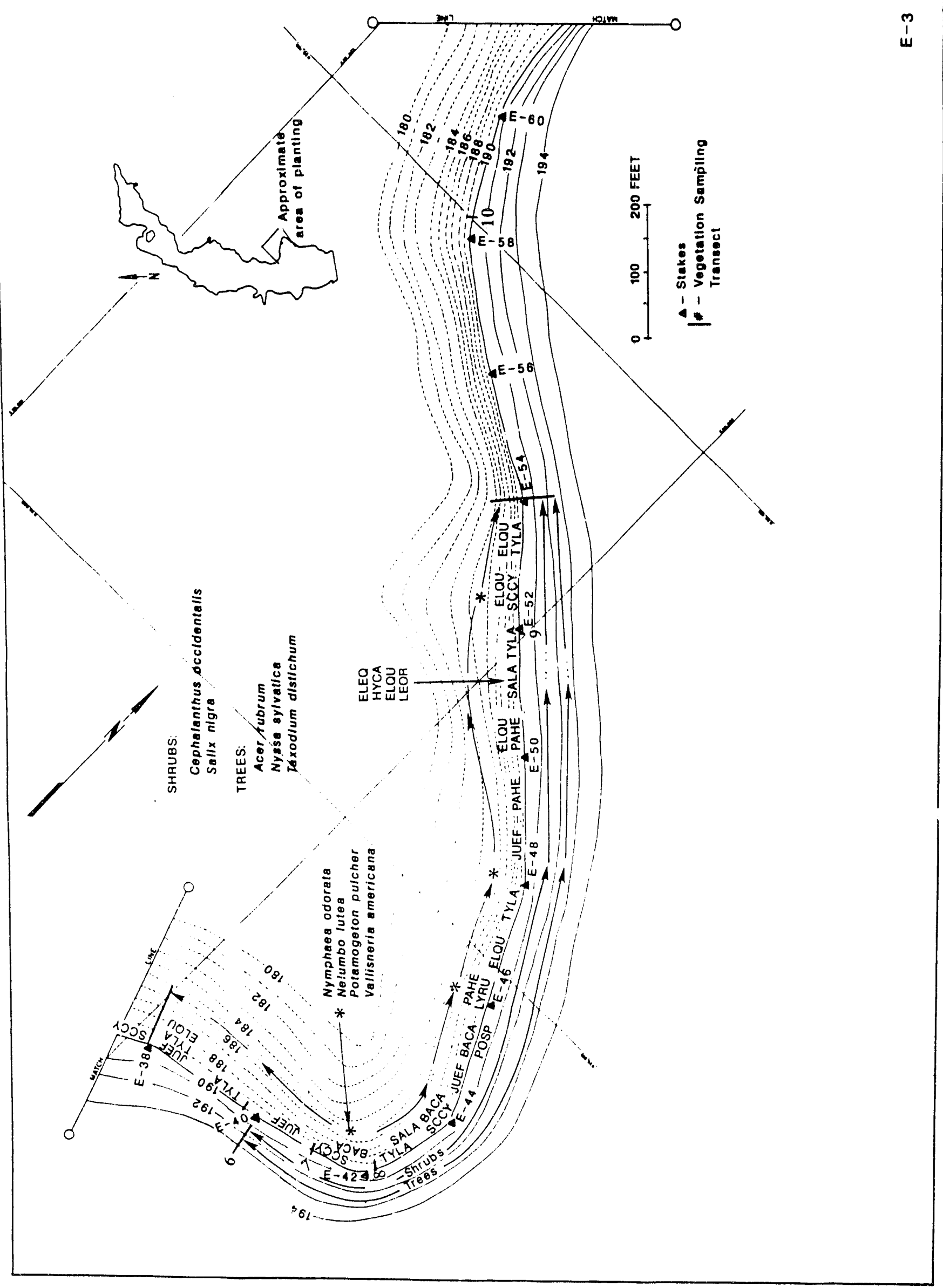




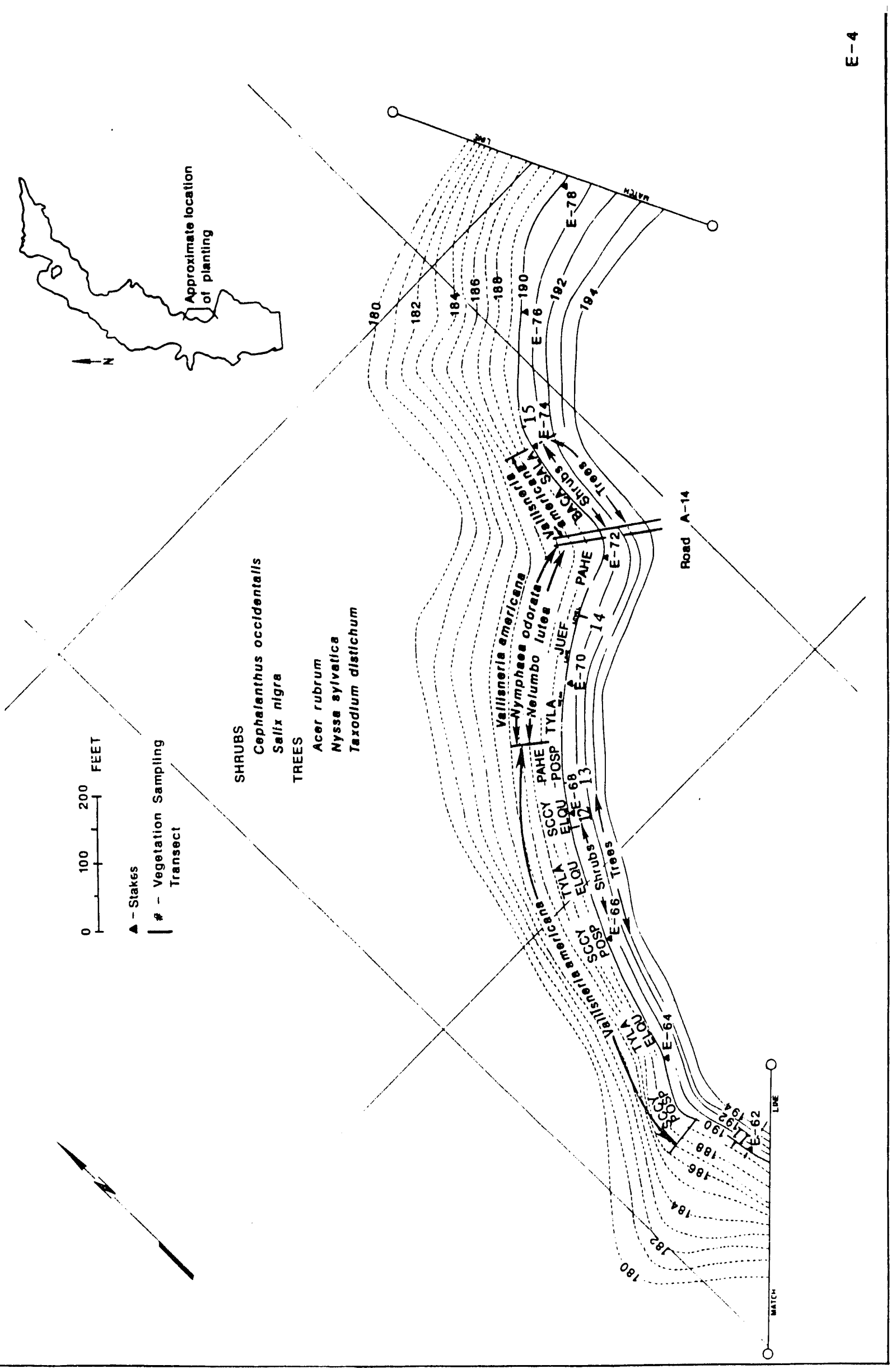




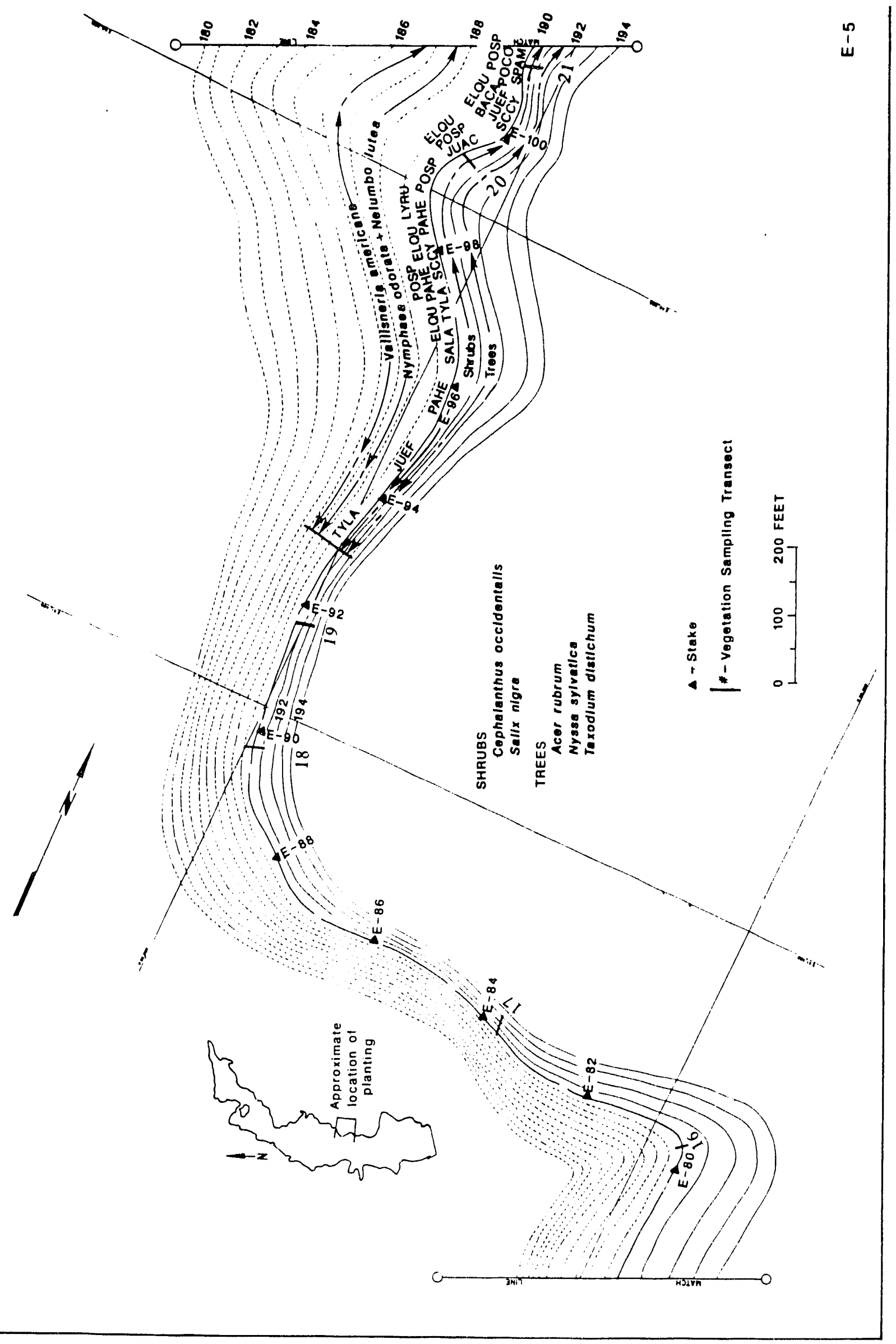




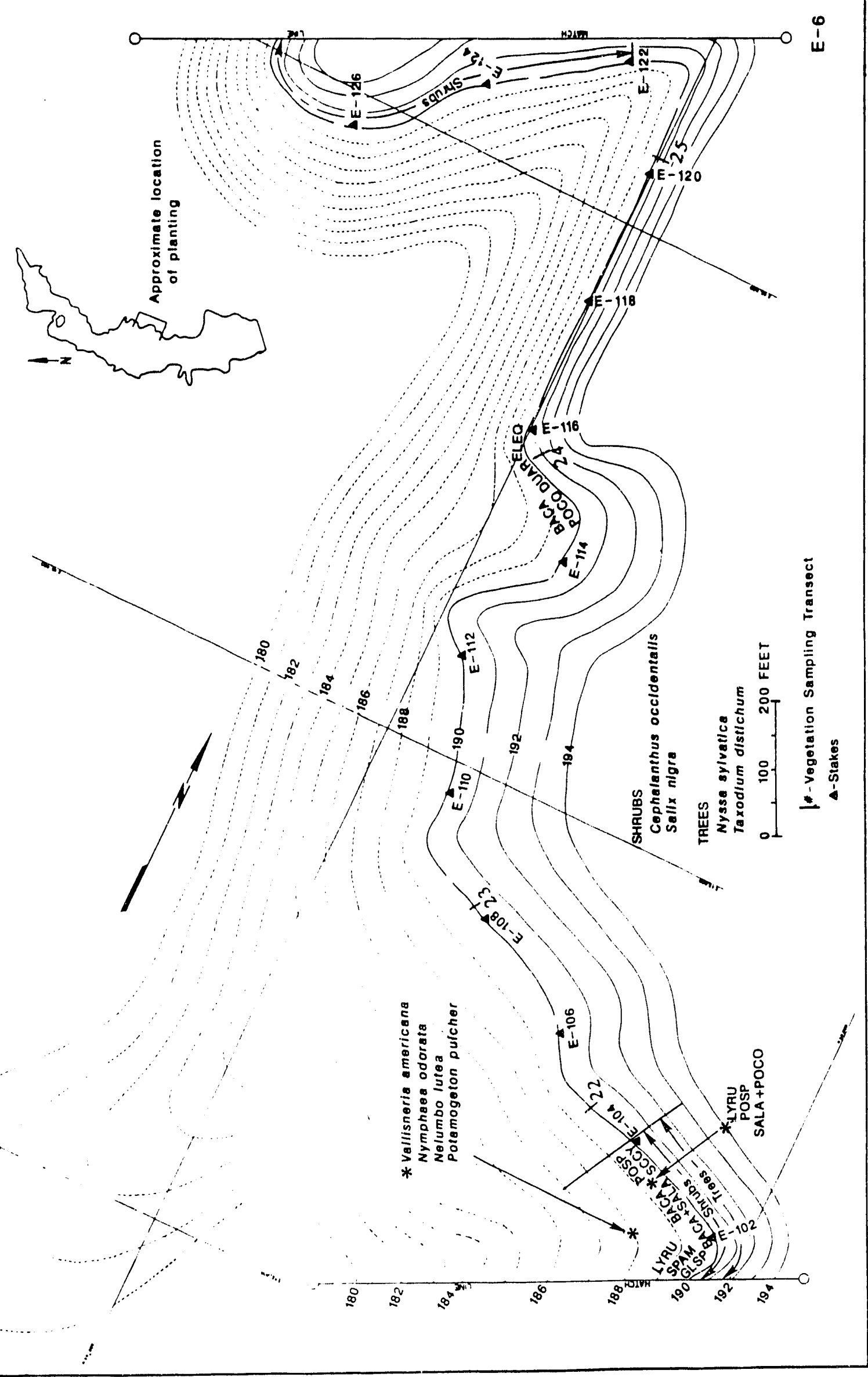




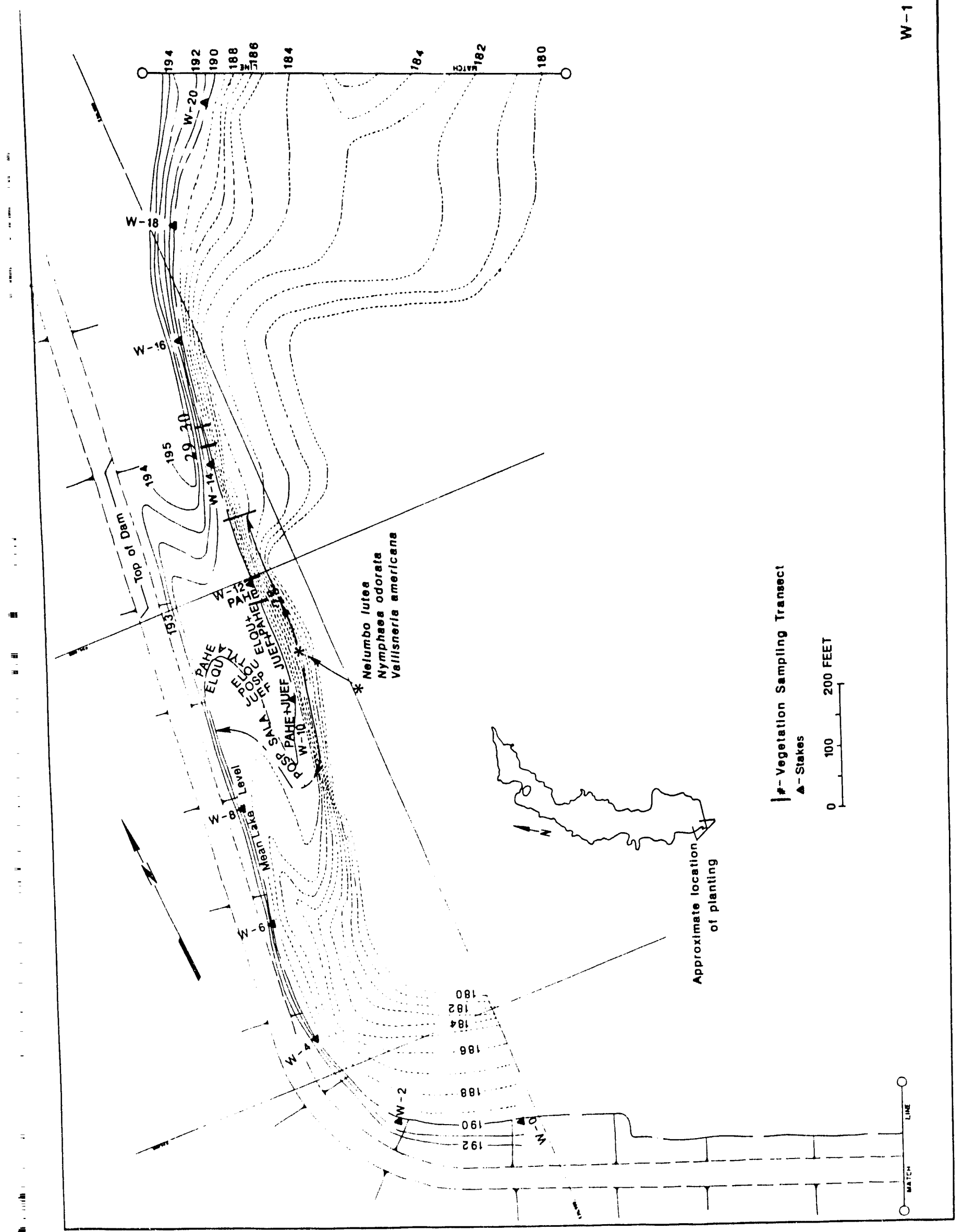




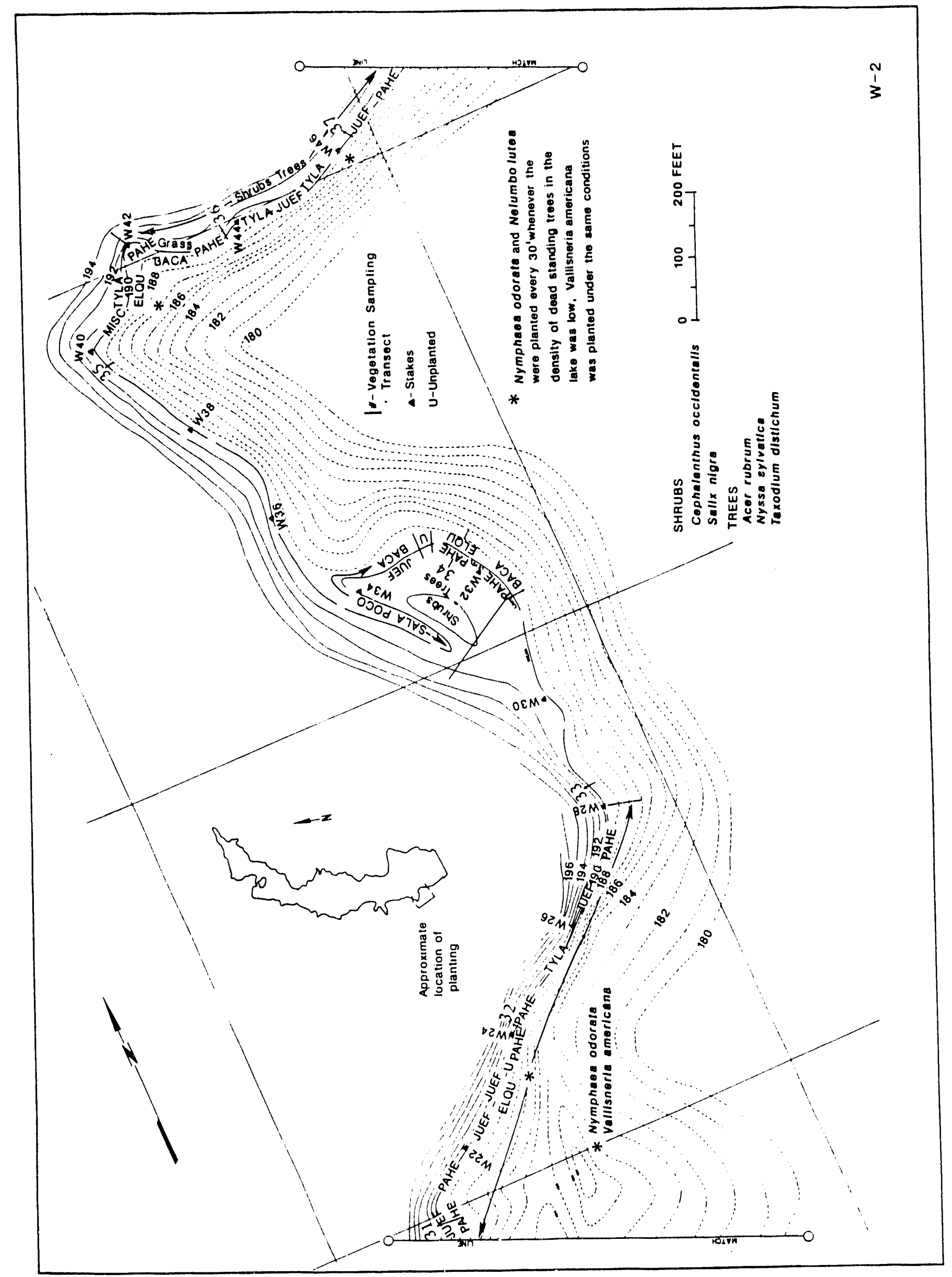




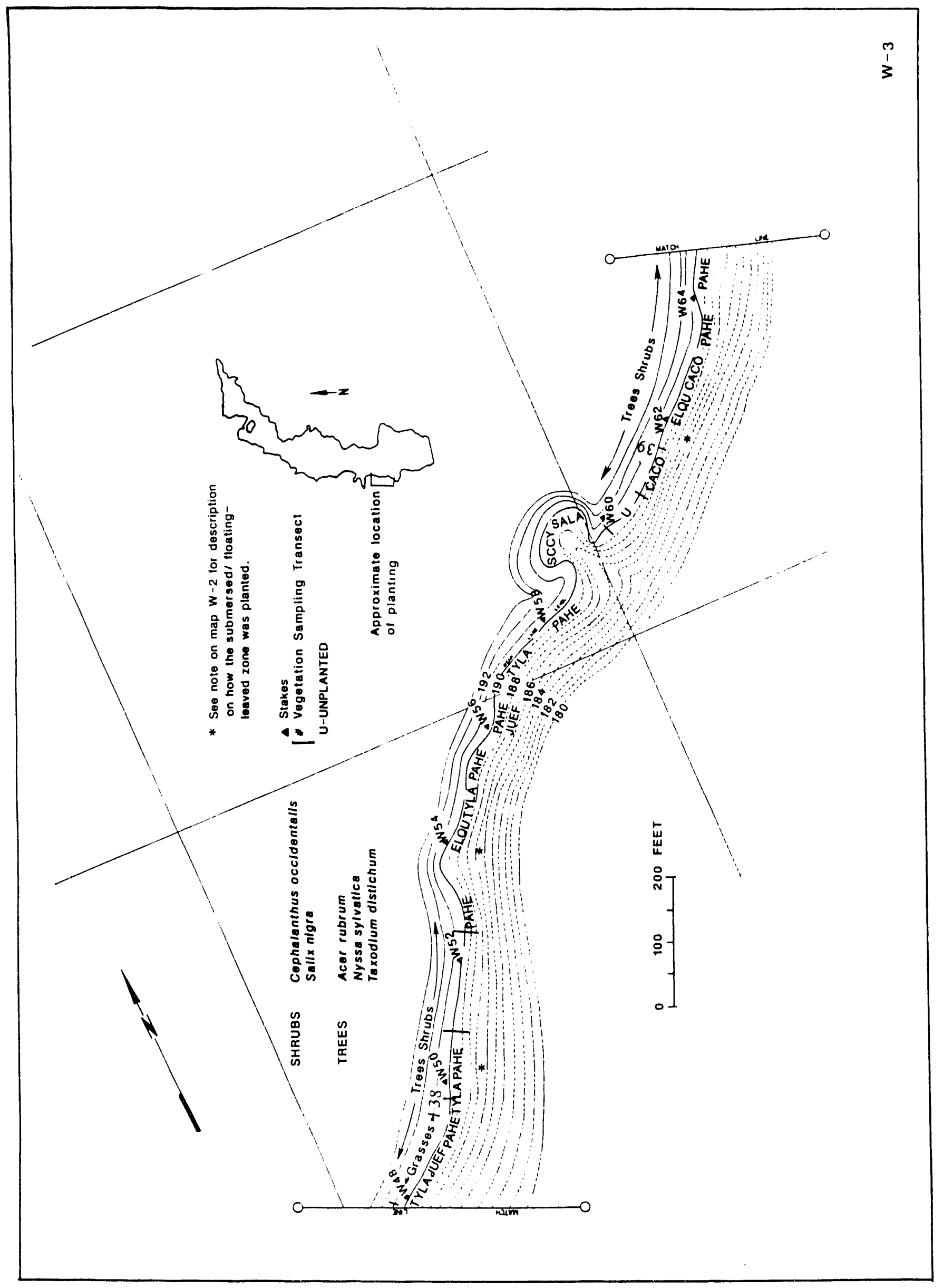




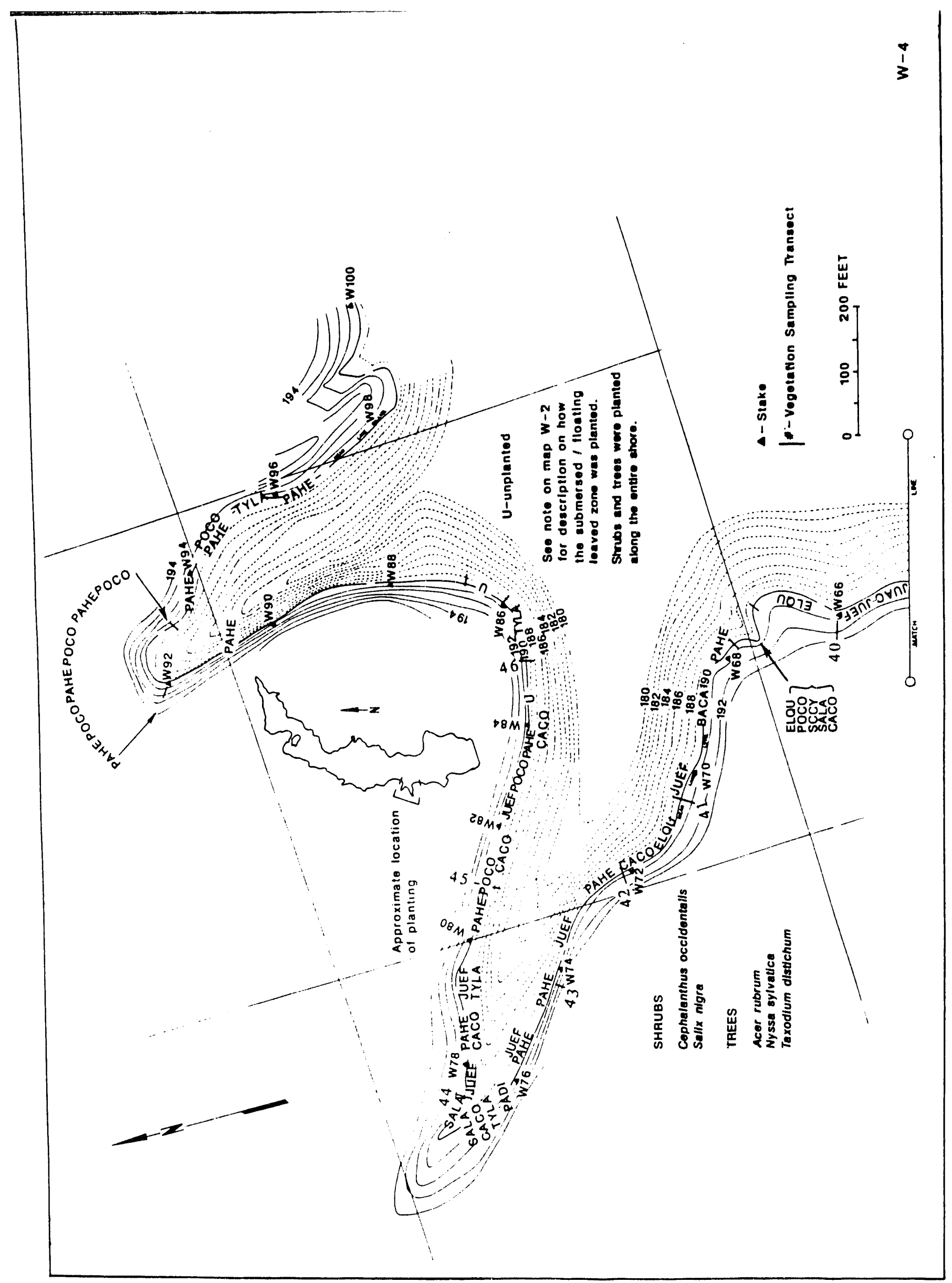




\section{Appendix B: Vegetation sampled during 1987, 1988 and 1989}

This appendix summarizes all species sampled in each of the three zones between planted and unplanted areas. Species are listed alphabetically by zone. Frequency, the number of plots in which a species occurred, is denoted by $\mathrm{N}$. Cover refers to the sum of the species cover. For example, in the submersed/floating-leaved zone in planted areas, Alternanthera philoxeroides occurred in six plots in 1988; its total cover in 1988 was $125 \%$. 
Submersered/Floating-leaved zone, Planted

\begin{tabular}{|c|c|c|c|}
\hline Species & Year & $\mathrm{N}$ & Cover \\
\hline Alternanthera philoxeroides & $\begin{array}{l}1987 \\
1988 \\
1989\end{array}$ & $\begin{array}{r}0 \\
6 \\
10\end{array}$ & $\begin{array}{r}0 \\
125 \\
84\end{array}$ \\
\hline Aneilema keisak & $\begin{array}{l}1987 \\
1988 \\
1989\end{array}$ & $\begin{array}{l}0 \\
0 \\
1\end{array}$ & $\begin{array}{l}0 \\
0 \\
1\end{array}$ \\
\hline Eleocharis equisetoides & $\begin{array}{l}1987 \\
1988 \\
1989\end{array}$ & $\begin{array}{l}2 \\
1 \\
0\end{array}$ & $\begin{array}{r}2 \\
10 \\
0\end{array}$ \\
\hline Eleocharis quadrangulata & $\begin{array}{l}1987 \\
1988 \\
1989\end{array}$ & $\begin{array}{l}1 \\
0 \\
2\end{array}$ & $\begin{array}{l}5 \\
0 \\
2\end{array}$ \\
\hline Empty plots & $\begin{array}{l}1987 \\
1988 \\
1989\end{array}$ & $\begin{array}{l}891 \\
779 \\
589\end{array}$ & $\dot{.}$ \\
\hline Hydrocotyle umbellata & $\begin{array}{l}1987 \\
1988 \\
1989\end{array}$ & $\begin{array}{r}0 \\
4 \\
19\end{array}$ & $\begin{array}{r}0 \\
125 \\
305\end{array}$ \\
\hline Nelumbo luteà & $\begin{array}{l}1987 \\
1988 \\
1989\end{array}$ & $\begin{array}{r}37 \\
134 \\
251\end{array}$ & $\begin{array}{r}322 \\
6505 \\
14087\end{array}$ \\
\hline Nymphaea odorata & $\begin{array}{l}1987 \\
1988 \\
1989\end{array}$ & $\begin{array}{r}34 \\
4 \\
0\end{array}$ & $\begin{array}{r}565 \\
85 \\
0\end{array}$ \\
\hline Paspalum sp. & $\begin{array}{l}1987 \\
1988 \\
1989\end{array}$ & $\begin{array}{l}0 \\
0 \\
3\end{array}$ & $\begin{array}{l}0 \\
0 \\
9\end{array}$ \\
\hline Polygonum sp. & $\begin{array}{l}1987 \\
1988 \\
1989\end{array}$ & $\begin{array}{l}1 \\
0 \\
0\end{array}$ & $\begin{array}{l}5 \\
0 \\
0\end{array}$ \\
\hline Sacciolepis striata & $\begin{array}{l}1987 \\
1988 \\
1989\end{array}$ & $\begin{array}{l}0 \\
1 \\
2\end{array}$ & $\begin{array}{l}0 \\
5 \\
2\end{array}$ \\
\hline Sagittaria latifolia & $\begin{array}{l}1987 \\
1988 \\
1989\end{array}$ & $\begin{array}{l}0 \\
0 \\
1\end{array}$ & $\begin{array}{l}0 \\
0 \\
2\end{array}$ \\
\hline
\end{tabular}


Submersered/Floating-leaved Zone, Planted

\begin{tabular}{lrrr} 
Species & Year & N & Cover \\
\cline { 2 - 4 } Typha latifolia & 1987 & 0 & 0 \\
& 1988 & 6 & 82 \\
& 1989 & 29 & 288 \\
Valiisneria americana & 1987 & 0 & 0 \\
& 1988 & 21 & 399 \\
& 1989 & 83 & 5674
\end{tabular}

Submersered/Floating-leaved Zone, Unplanted

species

Empty plots

Year

1987

1988

1989

Hydrocotyle umbellata

Typha latifolia
1987

1988

1989

1987

1988

1989
N Cover

786

785

781

$0 \quad 0$

15

11

$0 \quad 0$

$0 \quad 37$

$5 \quad 37$ 
Emergent Zone, Planted

Species

Alternanthera philoxeroides

Aneilema keisak

Bacopa caroliniana

Bidens sp.

Boehmeria cylindrica

Carex comosa

Carex sp.

Cephalanthus occidentalis

Cyperus esculentus

Cyperus sp.

Digitaria sp.

Echinochloa crusgalli

\begin{tabular}{crr} 
Year & \multicolumn{1}{r}{$N$} & Cover \\
\cline { 2 - 3 } & & \\
1987 & 22 & 158 \\
1988 & 41 & 768 \\
1989 & 72 & 610 \\
1987 & 3 & 30 \\
1988 & 5 & 221 \\
1989 & 8 & 111 \\
1987 & 4 & 115 \\
1988 & 7 & 290 \\
1989 & 9 & 299 \\
1987 & 3 & 11 \\
1988 & 5 & 8 \\
1989 & 0 & 0
\end{tabular}

1987

1988

1989

1987

1988

1989

1987

1988

1989

1987

1988

1989

1987

1988

1989

1987

1988

1989

1987

1988

1989

1987

1988

1989

\section{8}


Emergent Zone, Planted

species

Eclipta aloa

Eleocharis equisetoides

Eleocharis quadrangulata

Empty plots

Erechtites hieracifolia

Eupatorium sp.

Galium sp.

Gerardia sp.

Gnaphalium sp.

Hydrochloa caroliniensis

Hydrocotyle umbellata

Juncus effusus
Year

1987

1988

1989

1987

1988

1989

1987

1988

1989

1987

1988

1989

1987

1988

1939

1987

1988

1989

1987

1988

1989

1987

1988

1989

1987

1988

1989

1987

1988

1989

1987

1988

1989

1987

1988

1989
N Cover

$\begin{array}{rr}3 & 22 \\ 7 & 12 \\ 2 & 2\end{array}$

$11 \quad 42$

$17 \quad 536$

$10 \quad 64$

$35 \quad 877$

$53 \quad 2362$

$103 \quad 1893$

109

77

53

$\begin{array}{ll}0 & 0 \\ 1 & 2 \\ 2 & 2\end{array}$

$\begin{array}{ll}0 & 0 \\ 1 & 1 \\ 1 & 1\end{array}$

0

0

10

0

19

1

0

0

0

1

0

1

0

75

95

$10 \quad 83$

$4 \quad 19$

$40 \quad 540$

$94 \quad 390$

$27 \quad 199$

$32 \quad 675$

$39 \quad 1036$ 
Emergent Zone, Planted

species

Juncus megacephalus

Juncus sp.

Leersia oryzoides

Ludwigia alternifolia

Ludwigia decurrer...

Ludwigia leptocarpa

Ludwigia sp.

Lyc-pus rubellus

Lycopus virginicus

Mikania scandens

Nelumbo lutea

Nymphaea odorata
Year

1987.

1988

1989

1987

1988

1989

1987

1988

1989

1987

1988

1989

1987

1988

1989

1987

1988

1989

1987

1988

1989

1987

1988

1989

1987

1988

1989

1987

1988

1989

1987

1988

1989

1987

1988

1989
N Cover

$\begin{array}{rr}0 & 0 \\ 0 & 0 \\ 1 & 1 \\ 2 & 10 \\ 2 & 11 \\ 3 & 9\end{array}$

$\begin{array}{rr}1 & 10 \\ 2 & 18 \\ 23 & 99\end{array}$

$0 \quad 0$

$\begin{array}{ll}0 & 0 \\ 3 & 5\end{array}$

$0 \quad 0$

$6 \quad 39$

$0 \quad 0$

$8 \quad 54$

$8 \quad 22$

516

135

$0 \quad 0$

11

0

313

$0 \quad 0$

$\begin{array}{ll}0 & 0 \\ 2 & 2\end{array}$

2105

$5 \quad 10$

733

$31 \quad 294$

$58 \quad 1284$

$59 \quad 1032$

$10 \quad 151$

$\begin{array}{ll}1 & 5 \\ 0 & 0\end{array}$ 
Emergent Zone, Planted

\section{Species}

Panicum dichotomiflorum

Panicum hemitomon

Paspalum distichum

Paspalum sp.

Polygonum hydropiperoides

Polygonum persicaria

Polygonum sagittatum

Polygonum sp.

Pontederia cordata

Rubus sp.

Sacciolepis striata

Sagittaria latifolia

\section{$\underline{\text { Year }}$}

1987

1988

1989

1987

1988

1989

1987

1988

1989

1987

1988

1989

1987

1988

1989

1987

1988

1989

1987

1988

1989

1987

1988

1989

1987

1988

1989

1987

1988

1989

1987

1988

1989

1987

1988

1989 
Emergent Zone, Planted

Species

Salix nigra

scirpus cyperinus

setaria sp.

sparganium americanum

Typha latifolia

Unknown Apiaceae

Unknown Cyperaceae

Unknown Poaceae

Unknown Rosaceae

Unknowns

Vallisneria americana year

1987

1988

1989

1987

1988

1989

1987

1988

1989

1987

1988

1989

1987

1988

1989

1987

1988

1989

1987

1988

1989

1987

1988

1989

1987

1988

1989

1987

1988

1989

1987

1988

1989
N Cover

$\begin{array}{ll}11 & 240 \\ 12 & 317 \\ 14 & 293\end{array}$

$2 \quad 38$

15

11

$0 \quad 0$

23

12

$\begin{array}{ll}1 & 0 \\ 0 & 0\end{array}$

$31 \quad 782$

$64 \quad 1804$

$100 \quad 1115$

$\begin{array}{ll}0 & 0 \\ 1 & 5 \\ 0 & 0\end{array}$

$0 \quad 0$

$\begin{array}{ll}1 & 1 \\ 0 & 0\end{array}$

$20 \quad 1551$

12

11

$0 \quad 0$

$0 \quad 0$

11

1149

$0 \quad 0$

o

$17 \quad 289$

$55 \quad 2804$ 
Emergent Zone, Unplanted

Species

Alternanthera philoxeroides

Ambrosia artemisifolia

Ampelopsis arborea

Andropogon sp.

Aneilema keisak

Bacopa caroliniana

Berchemia scandens

Boehmeria cylindrica

Cassia fasciculata

Cyperus esculentus

Cyperus sp.

Digitaria sp.

\begin{tabular}{|c|c|c|}
\hline Year & $\mathrm{N}$ & Cover \\
\hline $\begin{array}{l}1987 \\
1988 \\
1989\end{array}$ & $\begin{array}{r}6 \\
14 \\
15\end{array}$ & $\begin{array}{l}276 \\
355 \\
241\end{array}$ \\
\hline $\begin{array}{l}1987 \\
1988 \\
1989\end{array}$ & $\begin{array}{l}0 \\
0 \\
1\end{array}$ & $\begin{array}{l}0 \\
0 \\
1\end{array}$ \\
\hline $\begin{array}{l}1987 \\
1988 \\
1989\end{array}$ & $\begin{array}{l}0 \\
1 \\
0\end{array}$ & $\begin{array}{l}0 \\
3 \\
0\end{array}$ \\
\hline $\begin{array}{l}1987 \\
1988 \\
1989\end{array}$ & $\begin{array}{l}0 \\
0 \\
2\end{array}$ & $\begin{array}{l}0 \\
0 \\
2\end{array}$ \\
\hline $\begin{array}{l}1987 \\
1988 \\
1989\end{array}$ & $\begin{array}{l}0 \\
1 \\
1\end{array}$ & $\begin{array}{l}0 \\
3 \\
1\end{array}$ \\
\hline $\begin{array}{l}1987 \\
1988 \\
1989\end{array}$ & $\begin{array}{l}0 \\
0 \\
1\end{array}$ & $\begin{array}{l}0 \\
0 \\
2\end{array}$ \\
\hline $\begin{array}{l}1987 \\
1988 \\
1989\end{array}$ & $\begin{array}{l}0 \\
0 \\
1\end{array}$ & $\begin{array}{l}0 \\
0 \\
1\end{array}$ \\
\hline $\begin{array}{l}1987 \\
1988 \\
1989\end{array}$ & $\begin{array}{l}0 \\
0 \\
1\end{array}$ & $\begin{array}{l}0 \\
0 \\
1\end{array}$ \\
\hline $\begin{array}{l}1987 \\
1988 \\
1989\end{array}$ & $\begin{array}{l}0 \\
0 \\
1\end{array}$ & $\begin{array}{l}0 \\
0 \\
1\end{array}$ \\
\hline $\begin{array}{l}1987 \\
1988 \\
1989\end{array}$ & $\begin{array}{l}9 \\
1 \\
0\end{array}$ & $\begin{array}{r}55 \\
3 \\
0\end{array}$ \\
\hline $\begin{array}{l}1987 \\
1988 \\
1989\end{array}$ & $\begin{array}{l}1 \\
1 \\
0\end{array}$ & $\begin{array}{l}1 \\
1 \\
0\end{array}$ \\
\hline $\begin{array}{l}1987 \\
1988 \\
1989\end{array}$ & $\begin{array}{l}2 \\
2 \\
0\end{array}$ & $\begin{array}{r}2 \\
110 \\
0\end{array}$ \\
\hline
\end{tabular}


Emergent zone, Unplanted

Species

Eclipta alba

Empty plots

Eupatorium sp.

Galium sp.

Gelsemium sempervirens

Hydrocotyle umbellata

Juncus sp.

Leersia oryzoides

Lespedeza sp.

Lonicera faponica

Ludwigia leptocarpa

Lycopus sp.

\begin{tabular}{|c|c|c|}
\hline Year & $\mathbf{N}$ & Cover \\
\hline $\begin{array}{l}1987 \\
1988 \\
1989\end{array}$ & $\begin{array}{l}0 \\
0 \\
1\end{array}$ & $\begin{array}{l}0 \\
0 \\
1\end{array}$ \\
\hline $\begin{array}{l}1987 \\
1988 \\
1989\end{array}$ & $\begin{array}{l}184 \\
192 \\
181\end{array}$ & $\dot{\cdot}$ \\
\hline $\begin{array}{l}1987 \\
1988 \\
1989\end{array}$ & $\begin{array}{l}1 \\
0 \\
1\end{array}$ & $\begin{array}{l}3 \\
0 \\
1\end{array}$ \\
\hline $\begin{array}{l}1987 \\
1988 \\
1989\end{array}$ & $\begin{array}{l}0 \\
0 \\
1\end{array}$ & $\begin{array}{l}0 \\
0 \\
1\end{array}$ \\
\hline $\begin{array}{l}1987 \\
1988 \\
1989\end{array}$ & $\begin{array}{l}2 \\
1 \\
1\end{array}$ & $\begin{array}{r}26 \\
30 \\
1\end{array}$ \\
\hline $\begin{array}{l}1987 \\
1988 \\
1989\end{array}$ & $\begin{array}{r}0 \\
7 \\
14\end{array}$ & $\begin{array}{r}0 \\
241 \\
28\end{array}$ \\
\hline $\begin{array}{l}1987 \\
1988 \\
1989\end{array}$ & $\begin{array}{l}0 \\
1 \\
3\end{array}$ & $\begin{array}{r}0 \\
2 \\
23\end{array}$ \\
\hline $\begin{array}{l}1987 \\
1988 \\
1989\end{array}$ & $\begin{array}{l}1 \\
1 \\
5\end{array}$ & $\begin{array}{l}10 \\
25 \\
70\end{array}$ \\
\hline $\begin{array}{l}1987 \\
1988 \\
1989\end{array}$ & $\begin{array}{l}0 \\
0 \\
1\end{array}$ & $\begin{array}{l}0 \\
0 \\
1\end{array}$ \\
\hline $\begin{array}{l}1987 \\
1988 \\
1989\end{array}$ & $\begin{array}{l}0 \\
0 \\
1\end{array}$ & $\begin{array}{r}0 \\
0 \\
10\end{array}$ \\
\hline $\begin{array}{l}1987 \\
1988 \\
1989\end{array}$ & $\begin{array}{r}11 \\
3 \\
1\end{array}$ & $\begin{array}{r}67 \\
7 \\
1\end{array}$ \\
\hline $\begin{array}{l}1987 \\
1988 \\
1989\end{array}$ & $\begin{array}{l}0 \\
0 \\
1\end{array}$ & $\begin{array}{l}0 \\
0 \\
3\end{array}$ \\
\hline
\end{tabular}


Emergent Zone, Unplanted

Species

Panicum dichotomiflorum

Panicum hemitomon

Paspalum sp.

Polygonum hydropiperoides

Polygonum sagittatum

Pontederia cordata

Poplar sp.

Rubus sp.

Sacciolepis striata

Sagittaria latifolia

Salix nigra

Solidago sp.

\begin{tabular}{|c|c|c|}
\hline Year & $\mathrm{N}$ & Cover \\
\hline $\begin{array}{l}1987 \\
1988 \\
1989\end{array}$ & $\begin{array}{l}0 \\
2 \\
2\end{array}$ & $\begin{array}{l}0 \\
2 \\
2\end{array}$ \\
\hline $\begin{array}{l}1987 \\
1988 \\
1989\end{array}$ & $\begin{array}{l}0 \\
0 \\
1\end{array}$ & $\begin{array}{l}0 \\
0 \\
1\end{array}$ \\
\hline $\begin{array}{l}1987 \\
1988 \\
1989\end{array}$ & $\begin{array}{l}0 \\
1 \\
0\end{array}$ & $\begin{array}{l}0 \\
1 \\
0\end{array}$ \\
\hline $\begin{array}{l}1987 \\
1988 \\
1989\end{array}$ & $\begin{array}{l}0 \\
1 \\
0\end{array}$ & $\begin{array}{l}0 \\
1 \\
0\end{array}$ \\
\hline $\begin{array}{l}1987 \\
1988 \\
1989\end{array}$ & $\begin{array}{l}0 \\
0 \\
1\end{array}$ & $\begin{array}{l}0 \\
0 \\
1\end{array}$ \\
\hline $\begin{array}{l}1987 \\
1988 \\
1989\end{array}$ & $\begin{array}{l}0 \\
0 \\
1\end{array}$ & $\begin{array}{l}0 \\
0 \\
1\end{array}$ \\
\hline $\begin{array}{l}1987 \\
1988 \\
1989\end{array}$ & $\begin{array}{l}0 \\
0 \\
1\end{array}$ & $\begin{array}{l}0 \\
0 \\
1\end{array}$ \\
\hline $\begin{array}{l}1987 \\
1988 \\
1989\end{array}$ & $\begin{array}{l}3 \\
1 \\
1\end{array}$ & $\begin{array}{l}3 \\
5 \\
2\end{array}$ \\
\hline $\begin{array}{l}1987 \\
1988 \\
1989\end{array}$ & $\begin{array}{l}0 \\
1 \\
0\end{array}$ & $\begin{array}{l}0 \\
1 \\
0\end{array}$ \\
\hline $\begin{array}{l}1987 \\
1988 \\
1989\end{array}$ & $\begin{array}{l}6 \\
4 \\
1\end{array}$ & $\begin{array}{r}90 \\
24 \\
2\end{array}$ \\
\hline $\begin{array}{l}1987 \\
1988 \\
1989\end{array}$ & $\begin{array}{l}0 \\
2 \\
5\end{array}$ & $\begin{array}{l}0 \\
4 \\
7\end{array}$ \\
\hline $\begin{array}{l}1987 \\
1988 \\
1989\end{array}$ & $\begin{array}{l}0 \\
0 \\
1\end{array}$ & $\begin{array}{l}0 \\
0\end{array}$ \\
\hline
\end{tabular}


Emergent Zone, Unplanted

Species

Typha latifolia

Unknown Asteraceae

Unknown Fabaceae

Unknown Poaceae

Unknowns

\begin{tabular}{crr} 
Year & N & Cover \\
\cline { 2 - 3 } 1987 & 0 & 0 \\
1988 & 6 & 97 \\
1989 & 15 & 109 \\
1987 & 0 & 0 \\
1988 & 1 & 1 \\
1989 & 0 & 0 \\
1987 & 0 & 0 \\
1988 & 0 & 0 \\
1989 & 1 & 1 \\
1987 & 8 & 221 \\
1988 & 1 & 10 \\
1989 & 1 & 1 \\
1987 & 4 & 7 \\
1988 & 0 & 0 \\
1989 & 1 & 1
\end{tabular}


Upper Emergent/Shrub Zone, Planted

Species

Acalypha gracilens

Acer negundo

Acer rubrum

Alternanthera philoxeroides

Ambrosia artemisifolia

Ambrosia sp.

Amuannia coccinea

Ampelopsis arborea

Andropogon sp.

Aneilema keisak

Baccharis halimifolia

Bacopa caroliniana

\begin{tabular}{rrr} 
Year & N & Cover \\
\cline { 2 - 3 } 1987 & 0 & 0 \\
1988 & 0 & 0 \\
1989 & 2 & 2 \\
1987 & 0 & 0 \\
1988 & 8 & 13 \\
1989 & 9 & 17 \\
1987 & 13 & 26 \\
1988 & 30 & 94 \\
1989 & 20 & 127 \\
& & \\
1987 & 13 & 98 \\
1988 & 92 & 482 \\
1989 & 105 & 365 \\
1987 & & \\
1988 & 5 & 9 \\
1989 & 5 & 9 \\
& 10 & 10
\end{tabular}

1987

1988

1989

$1 \quad 1$

$\begin{array}{ll}3 & 3 \\ 0 & 0\end{array}$

1987

1988

1989

$0 \quad 0$

44

1987

1988

1989

0

0

1987

1988

1989

$0 \quad 0$

313

510

1987

1988

1989

$18 \quad 199$

$58 \quad 456$

$99 \quad 865$

1987

1988

1989

$\begin{array}{rr}0 & 0 \\ 28 & 59 \\ 33 & 209\end{array}$

0

0

1

0

1987

1988

12

22

82

1989

14

141

147 
Upper Emergent/Shrub Zone, Planted

Species _.

Berchemia scandens

Bidens sp.

Boehmeria cylindrica

Carex comosa

Carex sp.

carya tomentosa

Cassia fascjculata

Celtis laevigata

celtis sp.

Centrosema virginianum

Cephalanthus occidentalis

Clitoria mariana

\begin{tabular}{|c|c|c|}
\hline Year & $N$ & Cover \\
\hline $\begin{array}{l}1987 \\
1988 \\
1989\end{array}$ & $\begin{array}{l}4 \\
5 \\
4\end{array}$ & $\begin{array}{l}35 \\
27 \\
14\end{array}$ \\
\hline $\begin{array}{l}1987 \\
1988 \\
1989\end{array}$ & $\begin{array}{r}20 \\
39 \\
9\end{array}$ & $\begin{array}{r}126 \\
100 \\
13\end{array}$ \\
\hline $\begin{array}{l}1987 \\
1988 \\
1989\end{array}$ & $\begin{array}{r}65 \\
123 \\
142\end{array}$ & $\begin{array}{r}944 \\
1264 \\
1425\end{array}$ \\
\hline $\begin{array}{l}1987 \\
1988 \\
1989\end{array}$ & $\begin{array}{l}0 \\
1 \\
2\end{array}$ & $\begin{array}{l}0 \\
2 \\
8\end{array}$ \\
\hline $\begin{array}{l}1987 \\
1988 \\
1989\end{array}$ & $\begin{array}{r}4 \\
7 \\
11\end{array}$ & $\begin{array}{l}13 \\
33 \\
25\end{array}$ \\
\hline $\begin{array}{l}1987 \\
1988 \\
1989\end{array}$ & $\begin{array}{l}2 \\
3 \\
2\end{array}$ & $\begin{array}{r}4 \\
11 \\
3\end{array}$ \\
\hline $\begin{array}{l}1987 \\
1988 \\
1989\end{array}$ & $\begin{array}{l}4 \\
8 \\
6\end{array}$ & $\begin{array}{r}17 \\
15 \\
6\end{array}$ \\
\hline $\begin{array}{l}1987 \\
1988 \\
1989\end{array}$ & $\begin{array}{l}1 \\
0 \\
1\end{array}$ & $\begin{array}{l}3 \\
0 \\
2\end{array}$ \\
\hline $\begin{array}{l}1987 \\
1988 \\
1989\end{array}$ & $\begin{array}{l}0 \\
1 \\
0\end{array}$ & $\begin{array}{l}0 \\
3 \\
0\end{array}$ \\
\hline $\begin{array}{l}1987 \\
1988 \\
1989\end{array}$ & $\begin{array}{r}0 \\
0 \\
14\end{array}$ & $\begin{array}{r}0 \\
0 \\
28\end{array}$ \\
\hline $\begin{array}{l}1987 \\
1988 \\
1989\end{array}$ & $\begin{array}{l}13 \\
27 \\
30\end{array}$ & $\begin{array}{r}51 \\
133 \\
114\end{array}$ \\
\hline $\begin{array}{l}1987 \\
1988 \\
1989\end{array}$ & $\begin{array}{l}2 \\
9 \\
0\end{array}$ & $\begin{array}{r}25 \\
42 \\
0\end{array}$ \\
\hline
\end{tabular}


Upper Emergent/Shrub Zone, Planted

species .

Cornus florida

Crataegus sp.

Cyperus esculentus

Cyperus sp.

Digitaria sp.

Diodia sp.

Diospyros virginiana

Echinochloa crusgalli

Echinodorus cordifolius

Eclipta alba

Eleocharis acicularis

Eleocharis quadrangulata

\begin{tabular}{|c|c|c|}
\hline Year & $\mathbf{N}$ & Cover \\
\hline $\begin{array}{l}1987 \\
1988 \\
1989\end{array}$ & $\begin{array}{l}0 \\
1 \\
1\end{array}$ & $\begin{array}{l}0 \\
3 \\
5\end{array}$ \\
\hline $\begin{array}{l}1987 \\
1988 \\
1989\end{array}$ & $\begin{array}{l}0 \\
0 \\
1\end{array}$ & $\begin{array}{l}0 \\
0 \\
1\end{array}$ \\
\hline $\begin{array}{l}1987 \\
1988 \\
1989\end{array}$ & $\begin{array}{r}37 \\
5 \\
0\end{array}$ & $\begin{array}{r}114 \\
23 \\
0\end{array}$ \\
\hline $\begin{array}{l}1987 \\
1988 \\
1989\end{array}$ & $\begin{array}{r}6 \\
24 \\
11\end{array}$ & $\begin{array}{l}18 \\
35 \\
13\end{array}$ \\
\hline $\begin{array}{l}1987 \\
1988 \\
1989\end{array}$ & $\begin{array}{l}88 \\
55 \\
12\end{array}$ & $\begin{array}{r}1719 \\
1425 \\
50\end{array}$ \\
\hline $\begin{array}{l}1987 \\
1988 \\
1989\end{array}$ & $\begin{array}{r}0 \\
4 \\
10\end{array}$ & $\begin{array}{r}0 \\
4 \\
16\end{array}$ \\
\hline $\begin{array}{l}1987 \\
1988 \\
1989\end{array}$ & $\begin{array}{l}1 \\
2 \\
4\end{array}$ & $\begin{array}{r}5 \\
23 \\
39\end{array}$ \\
\hline $\begin{array}{l}1987 \\
1988 \\
1989\end{array}$ & $\begin{array}{r}11 \\
0 \\
0\end{array}$ & $\begin{array}{r}253 \\
0 \\
0\end{array}$ \\
\hline $\begin{array}{l}1987 \\
1988 \\
1989\end{array}$ & $\begin{array}{l}3 \\
2 \\
5\end{array}$ & $\begin{array}{r}11 \\
11 \\
6\end{array}$ \\
\hline $\begin{array}{l}1987 \\
1988 \\
1989\end{array}$ & $\begin{array}{l}71 \\
45 \\
16\end{array}$ & $\begin{array}{r}1159 \\
80 \\
17\end{array}$ \\
\hline $\begin{array}{l}1987 \\
1988 \\
1989\end{array}$ & $\begin{array}{l}0 \\
0 \\
1\end{array}$ & $\begin{array}{l}0 \\
0 \\
3\end{array}$ \\
\hline $\begin{array}{l}1987 \\
1988 \\
1989\end{array}$ & $\begin{array}{l}2 \\
9 \\
6\end{array}$ & $\begin{array}{r}2 \\
60 \\
16\end{array}$ \\
\hline
\end{tabular}


Upper Emergent/Shrub Zone, Planted

species
Empty plots
Erechtites hieracifolia
Erianthus giganteus
Erigeron sp.

Year

1987

1988

1989

1987

1988

1989

1987

1988

1989

1987

1988

1989

Eupatorium sp.

Euphorbia sp.

Galium sp.

Gelsemium sempervirens

Gerardia sp.

Gnaphalium sp.

Habenaria repens

Helenium amarum
1987

1988

1989

1987

1988

1989

1987

1988

1989

1987

1988

1989

1987

1988

1989

1987

1988

1989

1987

1988

1989

1987

1988

1989

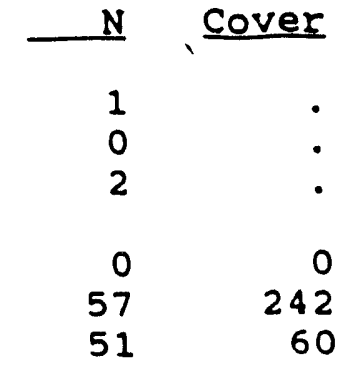

$0 \quad 0$

$0 \quad 0$

23

$0 \quad 0$

$59 \quad 186$

$6 \quad 49$

95.519

$88 \quad 452$

$\begin{array}{rr}2 & 25 \\ 0 & 0 \\ 4 & 8\end{array}$

$7 \quad 39$

$10 \quad 50$

$11 \quad 15$

210

$23 \quad 110$

$33 \quad 164$

39

$20 \quad 125$

413

11

$14 \quad 15$

$10 \quad 32$

$\begin{array}{rr}0 & 0 \\ 0 & 0 \\ 9 & 15\end{array}$

$\begin{array}{rr}0 & 0 \\ 0 & 0 \\ 11 & 16\end{array}$


Upper Emergent/Shrub Zone, Planted

species _

\begin{tabular}{lrr} 
Year & N & Cover \\
\cline { 2 - 3 } 1987 & 0 & 0 \\
1988 & 0 & 0 \\
1989 & 1 & 1 \\
1987 & 14 & 68 \\
1988 & 47 & 478 \\
1989 & 47 & 83 \\
1987 & 1 & 5 \\
1988 & 3 & 3 \\
1989 & 3 & 5
\end{tabular}

Hypericum gentianoides

1989

5

Hypericum sp.

1987

1988

1989

15

5

10

Hypericum walteri

1987

1988

1989

1987

Impatiens capensis

1988

1989

1987

Juncus biflorus

1988

1989

1987

1988

1989

0

0

0

0

Juncus effusus

1987

Juncus megacephalus

1988

1989

40

$\begin{array}{rr}7 & 19 \\ 6 & 8\end{array}$

Juncus megacephalus

Juncus scirpoides

1987

1988

1989

$\begin{array}{rr}0 & 0 \\ 0 & 0 \\ 26 & 108\end{array}$

1987

1988

1989

$9 \quad 53$

132210

$23 \quad 317$

Juncus sp.

1987

1988

1989

$\begin{array}{ll}0 & 0 \\ 0 & 0 \\ 1 & 1\end{array}$

Lactuca sp.

$\begin{array}{ll}0 & 0 \\ 0 & 0 \\ 1 & 1\end{array}$

$12 \quad 77$

$33 \quad 174$

1123

$\begin{array}{ll}0 & 0 \\ 0 & 0 \\ 6 & 7\end{array}$


Upper Emergent/Shrub Zone, Planted

species .

Leersia oryzoides

Lespedeza sp.

Liquidambar styraciflua

Lonicera japonica

Lonicera sp.

Ludwigia alternifolia

Ludwigia decurrens

Ludwigia leptocarpa

Ludwigia sp.

Lycopus rubellus

Lycopus sp.

Lycopus virginicus
Year

1987

1988

1989

1987

1988

1989

1987

1988

1989

1987

1988

1989

1987

1988

1989

1987

1988

1989

1987

1988

1989

1987

1988

1989

1987

1988

1989

1987

1988

1989

1987

1988

1989

1987

1988

1989
N Cover

$11 \quad 64$

$27 \quad 148$

$31 \quad 161$

$0 \quad 0$

$\begin{array}{ll}1 & 8 \\ 5 & 5\end{array}$

15

0
4

0

0

15

6

$\begin{array}{ll}0 & 0 \\ 0 & 0\end{array}$

$0 \quad 0$

38

$11 \quad 16$

$0 \quad 0$

34

12

$102 \quad 1199$

$61 \quad 175$

$18 \quad 22$

$0 \quad 0$

$\begin{array}{ll}1 & 1 \\ 0 & 0\end{array}$

$14 \quad 40$

1466

1890

$5 \quad 48$

15

610

0
0 21 48 
Upper Emergent/Shrub Zone, Planted

\begin{tabular}{|c|c|c|c|}
\hline Species & year & $\mathbf{N}$ & Cover \\
\hline Mikania scandens & $\begin{array}{l}1987 \\
1988 \\
1989\end{array}$ & $\begin{array}{r}8 \\
44 \\
63\end{array}$ & $\begin{array}{l}286 \\
177 \\
317\end{array}$ \\
\hline Modiola caroliniana & $\begin{array}{l}1987 \\
1988 \\
1989\end{array}$ & $\begin{array}{l}0 \\
0 \\
1\end{array}$ & $\begin{array}{l}0 \\
0 \\
1\end{array}$ \\
\hline Myrica cerifera & $\begin{array}{l}1987 \\
1988 \\
1989\end{array}$ & $\begin{array}{l}11 \\
21 \\
23\end{array}$ & $\begin{array}{r}93 \\
194 \\
337\end{array}$ \\
\hline Nelumbo lutea & $\begin{array}{l}1987 \\
1988 \\
1989\end{array}$ & $\begin{array}{l}0 \\
1 \\
0\end{array}$ & $\begin{array}{r}0 \\
10 \\
0\end{array}$ \\
\hline Nymphaea odorata & $\begin{array}{l}1987 \\
1988 \\
1989\end{array}$ & $\begin{array}{l}1 \\
0 \\
0\end{array}$ & $\begin{array}{l}1 \\
0 \\
0\end{array}$ \\
\hline Nyssa sylvatica & $\begin{array}{l}1987 \\
1988 \\
1989\end{array}$ & $\begin{array}{l}0 \\
0 \\
1\end{array}$ & $\begin{array}{l}0 \\
0 \\
2\end{array}$ \\
\hline Panicum dichotomiflorum & $\begin{array}{l}1987 \\
1988 \\
1989\end{array}$ & $\begin{array}{l}0 \\
9 \\
1\end{array}$ & $\begin{array}{r}0 \\
29 \\
1\end{array}$ \\
\hline Panicum hemitomon & $\begin{array}{l}1987 \\
1988 \\
1989\end{array}$ & $\begin{array}{l}30 \\
64 \\
98\end{array}$ & $\begin{array}{r}248 \\
929 \\
1507\end{array}$ \\
\hline Panicum sp. & $\begin{array}{l}1987 \\
1988 \\
1989\end{array}$ & $\begin{array}{l}14 \\
26 \\
25\end{array}$ & $\begin{array}{l}83 \\
77 \\
68\end{array}$ \\
\hline Parthenocissus quinquefolia & $\begin{array}{l}1987 \\
1988 \\
1989\end{array}$ & $\begin{array}{l}0 \\
1 \\
4\end{array}$ & $\begin{array}{r}0 \\
2 \\
17\end{array}$ \\
\hline Paspalum distichum & $\begin{array}{l}1987 \\
1988 \\
1989\end{array}$ & $\begin{array}{r}15 \\
0 \\
0\end{array}$ & $\begin{array}{r}345 \\
0 \\
0\end{array}$ \\
\hline Paspalum sp. & $\begin{array}{l}1987 \\
1988 \\
1989\end{array}$ & $\begin{array}{r}0 \\
22 \\
13\end{array}$ & $\begin{array}{r}0 \\
337 \\
25\end{array}$ \\
\hline
\end{tabular}


Upper Emergent/Shrub Zone, Planted

Species

Passiflora incarnata

Petalostemum pinnatum

Physalis sp.

Pinus taeda

Platanus occidentalis

Pluchea purpurascens

Polygonum densiflorun

Polygonin hydropiperoides

Polygonum persicaria

Polygonum sagittatum

Polygonum sp.

Polypremum procumbens

\begin{tabular}{|c|c|c|}
\hline Year & $N$ & Cover \\
\hline $\begin{array}{l}1987 \\
1988 \\
1989\end{array}$ & $\begin{array}{l}2 \\
2 \\
2\end{array}$ & $\begin{array}{r}6 \\
17 \\
2\end{array}$ \\
\hline $\begin{array}{l}1987 \\
1988 \\
1989\end{array}$ & $\begin{array}{l}2 \\
0 \\
0\end{array}$ & $\begin{array}{l}2 \\
0 \\
0\end{array}$ \\
\hline $\begin{array}{l}1987 \\
1988 \\
1989\end{array}$ & $\begin{array}{l}2 \\
0 \\
0\end{array}$ & $\begin{array}{r}10 \\
0 \\
0\end{array}$ \\
\hline $\begin{array}{l}1987 \\
1988 \\
1989\end{array}$ & $\begin{array}{r}2 \\
20 \\
25\end{array}$ & $\begin{array}{r}2 \\
26 \\
50\end{array}$ \\
\hline $\begin{array}{l}1987 \\
1988 \\
1989\end{array}$ & $\begin{array}{l}5 \\
5 \\
8\end{array}$ & $\begin{array}{l}15 \\
39 \\
81\end{array}$ \\
\hline $\begin{array}{l}1987 \\
1988 \\
1989\end{array}$ & $\begin{array}{l}1 \\
0 \\
0\end{array}$ & $\begin{array}{l}8 \\
0 \\
0\end{array}$ \\
\hline $\begin{array}{l}1987 \\
1988 \\
1989\end{array}$ & $\begin{array}{l}0 \\
0 \\
1\end{array}$ & $\begin{array}{l}0 \\
0 \\
1\end{array}$ \\
\hline $\begin{array}{l}1987 \\
1988 \\
1989\end{array}$ & $\begin{array}{r}0 \\
39 \\
33\end{array}$ & $\begin{array}{r}0 \\
209 \\
58\end{array}$ \\
\hline $\begin{array}{l}1987 \\
1988 \\
1989\end{array}$ & $\begin{array}{r}0 \\
59 \\
32\end{array}$ & $\begin{array}{r}0 \\
194 \\
34\end{array}$ \\
\hline $\begin{array}{l}1987 \\
1988 \\
1989\end{array}$ & $\begin{array}{l}0 \\
1 \\
4\end{array}$ & $\begin{array}{l}0 \\
1 \\
4\end{array}$ \\
\hline $\begin{array}{l}1987 \\
1988 \\
1989\end{array}$ & $\begin{array}{r}17 \\
4 \\
1\end{array}$ & $\begin{array}{r}118 \\
40 \\
1\end{array}$ \\
\hline $\begin{array}{l}1987 \\
1988 \\
1989\end{array}$ & $\begin{array}{r}7 \\
20 \\
8\end{array}$ & $\begin{array}{l}36 \\
60 \\
14\end{array}$ \\
\hline
\end{tabular}


Upper Emergent/Shrub Zone, Planted

Species -

Pontederia cordata

Poplar sp.

Potentilla sp.

Prunus sp.

Quercus nigra

Quercus sp.

Rhus copallina

Rhus radicans

Rhus sp.

Rubus sp.

Rumex sp.

sacciolepis striata

\section{Year}

1987

1988

1989

1987

1988

1989

1987

1988

1989

1987

1988

1989

1987

1988

1989

1987

1988

1989

1987

1988

1989

1987

1988

1989

1987

1988

1989

1987

1988

1989

1987

1988

1989

1987

1988

1989
N Cover

15

22

13

0

$\begin{array}{ll}0 & 0 \\ 1 & 1\end{array}$

$0 \quad 0$

$0 \quad 0$

11

$0 \quad 0$

$\begin{array}{ll}1 & 1 \\ 3 & 5\end{array}$

11

$\begin{array}{ll}1 & 1 \\ 0 & 0 \\ 0 & 0\end{array}$

$0 \quad 0$

$\begin{array}{ll}1 & 5 \\ 3 & 8\end{array}$

$4 \quad 30$

$10 \quad 57$

$11 \quad 31$

$0 \quad 0$

13

11

420

$\begin{array}{ll}0 & 0 \\ 0 & 0\end{array}$

$9 \quad 62$

$27 \quad 279$

$60 \quad 596$

$0 \quad 0$

$6 \quad 13$

1

626

$6 \quad 63$

$16 \quad 74$ 
Upper Emergent/Shrub Zone, Planted

\begin{tabular}{|c|c|c|c|}
\hline Species & Year & $\mathrm{N}$ & Cover \\
\hline Sagittaria latifolia & $\begin{array}{l}1987 \\
1988 \\
1989\end{array}$ & $\begin{array}{l}29 \\
27 \\
16\end{array}$ & $\begin{array}{r}380 \\
245 \\
45\end{array}$ \\
\hline Salix nigra & $\begin{array}{l}1987 \\
1988 \\
1989\end{array}$ & $\begin{array}{l}46 \\
65 \\
70\end{array}$ & $\begin{array}{r}948 \\
1532 \\
1616\end{array}$ \\
\hline scirpus cyperinus & $\begin{array}{l}1987 \\
1988 \\
1989\end{array}$ & $\begin{array}{l}10 \\
13 \\
16\end{array}$ & $\begin{array}{r}69 \\
127 \\
50\end{array}$ \\
\hline scutellaria sp. & $\begin{array}{l}1987 \\
1988 \\
1989\end{array}$ & $\begin{array}{l}0 \\
1 \\
6\end{array}$ & $\begin{array}{l}0 \\
2 \\
6\end{array}$ \\
\hline setaria sp. & $\begin{array}{l}1987 \\
1988 \\
1989\end{array}$ & $\begin{array}{l}0 \\
1 \\
0\end{array}$ & $\begin{array}{l}0 \\
2 \\
0\end{array}$ \\
\hline sida rhombifolia & $\begin{array}{l}1987 \\
1988 \\
1989\end{array}$ & $\begin{array}{r}9 \\
10 \\
5\end{array}$ & $\begin{array}{r}13 \\
24 \\
7\end{array}$ \\
\hline smilax sp. & $\begin{array}{l}1987 \\
1988 \\
1989\end{array}$ & $\begin{array}{l}0 \\
1 \\
2\end{array}$ & $\begin{array}{r}0 \\
2 \\
11\end{array}$ \\
\hline solanum sp. & $\begin{array}{l}1987 \\
1988 \\
1989\end{array}$ & $\begin{array}{l}0 \\
0 \\
1\end{array}$ & $\begin{array}{l}0 \\
0 \\
1\end{array}$ \\
\hline solidago sp. & $\begin{array}{l}1987 \\
1988 \\
1989\end{array}$ & $\begin{array}{l}5 \\
9 \\
6\end{array}$ & $\begin{array}{r}8 \\
17 \\
11\end{array}$ \\
\hline specularia perfoliata & $\begin{array}{l}1987 \\
1988 \\
1989\end{array}$ & $\begin{array}{l}1 \\
0 \\
0\end{array}$ & $\begin{array}{l}1 \\
0 \\
0\end{array}$ \\
\hline spigelia marilandica & $\begin{array}{l}1987 \\
1988 \\
1989\end{array}$ & $\begin{array}{l}0 \\
0 \\
1\end{array}$ & $\begin{array}{l}0 \\
0 \\
1\end{array}$ \\
\hline Taxodium distichum & $\begin{array}{l}1987 \\
1988 \\
1989\end{array}$ & $\begin{array}{l}2 \\
2 \\
2\end{array}$ & $\begin{array}{r}6 \\
10 \\
17\end{array}$ \\
\hline
\end{tabular}


Upper Emergent/Shrub Zone, Planted

\begin{tabular}{|c|c|c|c|}
\hline species & $\underline{\text { Year }}$ & $N$ & Cover \\
\hline Typha latifolia & $\begin{array}{l}1987 \\
1988 \\
1989\end{array}$ & $\begin{array}{l}46 \\
48 \\
18\end{array}$ & $\begin{array}{r}911 \\
775 \\
78\end{array}$ \\
\hline Ulmus sp. & $\begin{array}{l}1987 \\
1988 \\
1989\end{array}$ & $\begin{array}{l}0 \\
3 \\
3\end{array}$ & $\begin{array}{l}0 \\
3 \\
3\end{array}$ \\
\hline Unknown Apiaceae & $\begin{array}{l}1987 \\
1988 \\
1989\end{array}$ & $\begin{array}{l}0 \\
7 \\
0\end{array}$ & $\begin{array}{r}0 \\
29 \\
0\end{array}$ \\
\hline Unknown Asteraceae & $\begin{array}{l}1987 \\
1988 \\
1989\end{array}$ & $\begin{array}{l}16 \\
16 \\
27\end{array}$ & $\begin{array}{r}107 \\
25 \\
41\end{array}$ \\
\hline Unknown Cyperaceae & $\begin{array}{l}1987 \\
1988 \\
1989\end{array}$ & $\begin{array}{l}0 \\
2 \\
0\end{array}$ & $\begin{array}{l}0 \\
2 \\
0\end{array}$ \\
\hline Unknown Fabaceae & $\begin{array}{l}1987 \\
1988 \\
1989\end{array}$ & $\begin{array}{l}10 \\
19 \\
31\end{array}$ & $\begin{array}{r}85 \\
126 \\
222\end{array}$ \\
\hline Unknown Juncaceae & $\begin{array}{l}1987 \\
1988 \\
1989\end{array}$ & $\begin{array}{l}0 \\
1 \\
0\end{array}$ & $\begin{array}{l}0 \\
2 \\
0\end{array}$ \\
\hline Unknown Lamiaceae & $\begin{array}{l}1987 \\
1988 \\
1989\end{array}$ & $\begin{array}{r}5 \\
23 \\
1\end{array}$ & $\begin{array}{r}13 \\
56 \\
1\end{array}$ \\
\hline Unknown Poaceae & $\begin{array}{l}1987 \\
1988 \\
1989\end{array}$ & $\begin{array}{l}27 \\
53 \\
27\end{array}$ & $\begin{array}{r}300 \\
386 \\
77\end{array}$ \\
\hline Unknown Rubiaceae & $\begin{array}{l}1987 \\
1988 \\
1989\end{array}$ & $\begin{array}{l}8 \\
2 \\
0\end{array}$ & $\begin{array}{r}17 \\
2 \\
0\end{array}$ \\
\hline Unknown Solanaceae & $\begin{array}{l}1987 \\
1988 \\
1989\end{array}$ & $\begin{array}{l}3 \\
0 \\
0\end{array}$ & $\begin{array}{l}8 \\
0 \\
0\end{array}$ \\
\hline Unknowns & $\begin{array}{l}1987 \\
1988 \\
1989\end{array}$ & $\begin{array}{l}45 \\
30 \\
14\end{array}$ & $\begin{array}{r}608 \\
51 \\
15\end{array}$ \\
\hline
\end{tabular}


Upper Emergent/Shrub Zone, Planted

species _.

Vaccinium sp.

Vitis sp.

Wahlenbergia marginata

\begin{tabular}{crr} 
Year & N & Cover \\
\cline { 2 - 3 } 1987 & 0 & 0 \\
1988 & 2 & 20 \\
1989 & 2 & 18 \\
1987 & 0 & 0 \\
1988 & 14 & 70 \\
1989 & 13 & 59 \\
1987 & 0 & 0 \\
1988 & 2 & 4 \\
1989 & 1 & 1
\end{tabular}


Upper Emergent/Shrub Zone, Unplanted

Species _ _ _

Acalypha gracilens

Acer negundo

Acer rubrum

Alternanthera philoxeroides

Ambrosia artemisifolia

Ambrosia sp.

Ammannia coccinea

Ampelopsis arborea

Andropogon sp.

Aneilema keisak

Bacopa caroliniana

Berchemia scandens

\begin{tabular}{|c|c|c|}
\hline Year & $\mathrm{N}$ & Cover \\
\hline $\begin{array}{l}1987 \\
1988 \\
1989\end{array}$ & $\begin{array}{l}0 \\
0 \\
2\end{array}$ & $\begin{array}{l}0 \\
0 \\
2\end{array}$ \\
\hline $\begin{array}{l}1987 \\
1988 \\
1989\end{array}$ & $\begin{array}{l}0 \\
0 \\
1\end{array}$ & $\begin{array}{l}0 \\
0 \\
1\end{array}$ \\
\hline $\begin{array}{l}1987 \\
1988 \\
1989\end{array}$ & $\begin{array}{l}4 \\
4 \\
6\end{array}$ & $\begin{array}{l}11 \\
33 \\
39\end{array}$ \\
\hline $\begin{array}{l}1987 \\
1988 \\
1989\end{array}$ & $\begin{array}{l}27 \\
39 \\
72\end{array}$ & $\begin{array}{l}197 \\
346 \\
326\end{array}$ \\
\hline $\begin{array}{l}1987 \\
1988 \\
1989\end{array}$ & $\begin{array}{r}0 \\
5 \\
13\end{array}$ & $\begin{array}{r}0 \\
5 \\
16\end{array}$ \\
\hline $\begin{array}{l}1987 \\
1988 \\
1989\end{array}$ & $\begin{array}{l}2 \\
1 \\
1\end{array}$ & $\begin{array}{r}20 \\
1 \\
1\end{array}$ \\
\hline $\begin{array}{l}1987 \\
1988 \\
1989\end{array}$ & $\begin{array}{l}0 \\
1 \\
0\end{array}$ & $\begin{array}{l}0 \\
2 \\
0\end{array}$ \\
\hline $\begin{array}{l}1987 \\
1988 \\
1989\end{array}$ & $\begin{array}{l}0 \\
3 \\
1\end{array}$ & $\begin{array}{l}0 \\
9 \\
1\end{array}$ \\
\hline $\begin{array}{l}1987 \\
1988 \\
1989\end{array}$ & $\begin{array}{r}6 \\
17 \\
54\end{array}$ & $\begin{array}{r}31 \\
131 \\
572\end{array}$ \\
\hline $\begin{array}{l}1987 \\
1988 \\
1989\end{array}$ & $\begin{array}{r}0 \\
10 \\
20\end{array}$ & $\begin{array}{r}0 \\
280 \\
57\end{array}$ \\
\hline $\begin{array}{l}1987 \\
1988 \\
1989\end{array}$ & $\begin{array}{l}1 \\
5 \\
4\end{array}$ & $\begin{array}{l}2 \\
8 \\
9\end{array}$ \\
\hline $\begin{array}{l}1987 \\
1988 \\
1989\end{array}$ & $\begin{array}{l}0 \\
1 \\
3\end{array}$ & $\begin{array}{l}0 \\
1 \\
7\end{array}$ \\
\hline
\end{tabular}


Upper Emergent/Shrub Zone, Unplanted

species

Bidens sp.

Boehmeria cylindrica

Carex sp.

Cassia fasciculata

Cassia obtusifolia

Cephalanthus occidentalis

Crataegus sp.

Cyperus esculentus

Cyperus sp.

Digitaria sp.

Diodia sp.

Echinochloa crusgalli

\begin{tabular}{|c|c|c|}
\hline Year & $N$ & Cover \\
\hline $\begin{array}{l}1987 \\
1988 \\
1989\end{array}$ & $\begin{array}{r}13 \\
23 \\
7\end{array}$ & $\begin{array}{r}198 \\
115 \\
7\end{array}$ \\
\hline $\begin{array}{l}1987 \\
1988 \\
1989\end{array}$ & $\begin{array}{l}21 \\
43 \\
59\end{array}$ & $\begin{array}{r}89 \\
406 \\
501\end{array}$ \\
\hline $\begin{array}{l}1987 \\
1988 \\
1989\end{array}$ & $\begin{array}{l}0 \\
0 \\
3\end{array}$ & $\begin{array}{l}0 \\
0 \\
7\end{array}$ \\
\hline $\begin{array}{l}1987 \\
1988 \\
1989\end{array}$ & $\begin{array}{l}0 \\
4 \\
9\end{array}$ & $\begin{array}{r}0 \\
29 \\
22\end{array}$ \\
\hline $\begin{array}{l}1987 \\
1988 \\
1989\end{array}$ & $\begin{array}{l}0 \\
0 \\
1\end{array}$ & $\begin{array}{l}0 \\
0 \\
1\end{array}$ \\
\hline $\begin{array}{l}1987 \\
1988 \\
1989\end{array}$ & $\begin{array}{l}0 \\
5 \\
6\end{array}$ & $\begin{array}{r}0 \\
13 \\
11\end{array}$ \\
\hline $\begin{array}{l}1987 \\
1988 \\
1989\end{array}$ & $\begin{array}{l}0 \\
1 \\
1\end{array}$ & $\begin{array}{r}0 \\
20 \\
5\end{array}$ \\
\hline $\begin{array}{l}1987 \\
1988 \\
1989\end{array}$ & $\begin{array}{l}5 \\
4 \\
0\end{array}$ & $\begin{array}{r}21 \\
12 \\
0\end{array}$ \\
\hline $\begin{array}{l}1987 \\
1988 \\
1989\end{array}$ & $\begin{array}{l}13 \\
36 \\
21\end{array}$ & $\begin{array}{r}46 \\
160 \\
38\end{array}$ \\
\hline $\begin{array}{l}1987 \\
1988 \\
1989\end{array}$ & $\begin{array}{l}28 \\
24 \\
10\end{array}$ & $\begin{array}{l}771 \\
904 \\
203\end{array}$ \\
\hline $\begin{array}{l}1987 \\
1988 \\
1989\end{array}$ & $\begin{array}{l}0 \\
2 \\
3\end{array}$ & $\begin{array}{l}0 \\
2 \\
3\end{array}$ \\
\hline $\begin{array}{l}1987 \\
1988 \\
1989\end{array}$ & $\begin{array}{l}3 \\
0 \\
0\end{array}$ & $\begin{array}{l}8 \\
0 \\
0\end{array}$ \\
\hline
\end{tabular}


Upper Emergent/Shrub Zone, Unplanted

Species
Eclipta alba
Empty plots
Erechtites hieracifolia

Erigeron sp.

Eupatorium sp.

Fuirena squarrosa

Galium sp.

Gelsemium sempervirens

Gerardia sp.

Gnaphalium sp.

Habenaria repens

Helenium amarum

\begin{tabular}{lrr} 
Year & N & Cover \\
\cline { 3 - 3 } 1987 & 24 & 319 \\
1988 & 15 & 25 \\
1989 & 10 & 11 \\
1987 & 22 & \\
1988 & 10 & . \\
1989 & 6 & . \\
1987 & 0 & 0 \\
1988 & 18 & 35 \\
1989 & 13 & 27
\end{tabular}

1987

1988

1989

1987

1988

1989

$\begin{array}{rr}0 & 0 \\ 38 & 265 \\ 1 & 3\end{array}$

6

46

84

59

275

299

1987

1988

1989

1987

1988

1989

1987

1988

1989

1987

1988

1989

1987

1988

1989

1987

1988

1989

1987

1988

1989 $\begin{array}{ll}0 & 0\end{array}$

$0 \quad 0$

211

0

2

0

5

13

8

314

24

$0 \quad 0$

621

11

$\begin{array}{ll}1 & 1 \\ 7 & 7 \\ 2 & 3\end{array}$

$\begin{array}{ll}0 & 0 \\ 0 & 0 \\ 1 & 1\end{array}$

$\begin{array}{ll}0 & 0\end{array}$

$0 \quad 0$


Upper Emergent/Shrub Zone, Unplanted

species

Hydrocotyle umbellata

Hypericum gentianoides

Hypericum sp.

Impatiens capensis

Juncus biflorus

Juncus effusus

Juncus megacephalus

Juncus sp.

Leersia oryzoides

Lespedeza sp.

Lonicera japonica

Lonicera sempervirens year

1987

1988

1989

1987

1988

1989

1987

1988

1989

1987

1988

1989

1987

1988

1989

1987

1988

1989

1987

1988

1989

1987

1988

1989

1987

1988

1989

1987

1988

1989

1987

1988

1989

1987 1988 1989
N Cover

23

949

$21 \quad 61$

$\begin{array}{rr}0 & 0 \\ 8 & 14 \\ 1 & 1\end{array}$

11

$\begin{array}{ll}2 & 2 \\ 5 & 5\end{array}$

$0 \quad 0$

$3 \quad 3$

$0 \quad 0$

$0 \quad 0$

$0 \quad 0$

820

$0 \quad 0$

11

940

$\begin{array}{ll}0 & 0 \\ 0 & 0 \\ 4 & 8\end{array}$

$0 \quad 0$

1691

1581

$\begin{array}{rl}3 & 31 \\ 11 & 90 \\ 18 & 73\end{array}$

$0 \quad 0$

$0 \quad 0$

26

$0 \quad 0$

$0 \quad 0$

9166

$0 \quad 0$

$0 \quad 0$

12 
Upper Emergent/Shrub Zone, Unplanted

species

Ludwigia alternifolia

Ludwigia decurrens

Ludwigia leptocarpa

Ludwigia sp.

Lycopus rubellus

Lycopus sp.

Lycopus virginicus

Mikania scandens

Myrica cerifera

Panicum dichotomiflorum

Panicum hemitomon

Panicum sp.
Year

1987

1988

1989

1987

1988

1989

1987

1988

1989

1987

1988

1989

1987

1988

1989

1987

1988

1989

1987

1988

1989

1987

1988

1989

1987

1988

1989

1987

1988

1989

1987

1988

1989

1987

1988

1989
Cover

0

0

19

$0 \quad 0$

$6 \quad 32$

44

$40 \quad 384$

$49 \quad 562$

$22 \quad 37$

15

$\begin{array}{ll}0 & 0 \\ 1 & 1\end{array}$

$1 \quad 1$

$\begin{array}{lr}3 & 7 \\ 9 & 22\end{array}$

$0 \quad 0$

$0 \quad 0$

$11 \quad 36$

$0 \quad 0$

$16 \quad 63$

$20 \quad 75$

$0 \quad 0$

611

910

$0 \quad 0$

215

$8 \quad 27$

$0 \quad 0$

$13 \quad 47$

$6 \quad 86$

$\begin{array}{ll}0 & 0 \\ 3 & 7\end{array}$

$30 \quad 81$

$\begin{array}{lr}1 & 3 \\ 9 & 34 \\ 9 & 35\end{array}$


Upper Emergent/Shrub Zone, Unplanted

Species
Paspalum distichum
Paspalum sp.
Pinus taeda

\begin{tabular}{lrr} 
Year & N & Cover \\
\cline { 2 - 3 } 1987 & 0 & 0 \\
1988 & 1 & 1 \\
1989 & 0 & 0 \\
1987 & 0 & 0 \\
1988 & 9 & 90 \\
1989 & 10 & 20 \\
1987 & 0 & 0 \\
1988 & 8 & 9 \\
1989 & 8 & 14 \\
1987 & 2 & 3 \\
1988 & 2 & 13 \\
1989 & 2 & 6
\end{tabular}

Polygonum hydropiperoides

1987

1988

$0 \quad 0$

1989

8

31

22

61

Polygonum persicaria

1987

0

0

1988

1989

34

166

1987

Polygonum sagittatum

1988

1989

30 46

Polygonum sp.

1987

1988

1989

$\begin{array}{rr}2 & 15 \\ 5 & 26 \\ 9 & 114\end{array}$

8

2

44

Polypremum procumbens

1987

1988

1989

0

0

Pontederia cordata

1987

1988

1989

4
4
2

5

13

4
2

2

1987

1988

1989

$0 \quad 0$

15

15

Poplar sp.

1987

Quercus sp.

0

0

$0 \quad 0$

11

$\begin{array}{lr}0 & 0 \\ 2 & 54 \\ 3 & 58\end{array}$


Upper Emergent/Shrub Zone, Unplanted

species

Rhus copallina

Rubus sp.

Rumex sp.

sacciolepis striata

Sagittaria latifolia

salix nigra

scirpus cyperinus

scutellaria sp.

sida rhombifolia

smilax sp.

solidago sp.

specularia perfoliata

\section{Year}

1987

1988

1989

1987

1988

1989

1987

1988

1989

1987

1988

1989

1987

1988

1989

1987

1988

1989

1987

1988

1989

1987

1988

1989

1987

1988

1989

1987

1988

1989

1987

1988

1989

1987

1988

1989
N Cover

13

$3 \quad 32$

32

69

191

503

$0 \quad 0$

26

$0 \quad 0$

$0 \quad 0$

$\begin{array}{rr}3 & 21 \\ 0 & 0\end{array}$

$17 \quad 639$

18.180

$22 \quad 85$

$20 \quad 602$

$39 \quad 1118$

$55 \quad 1368$

$0 \quad 0$

$3 \quad 31$

$5 \quad 18$

$0 \quad 0$

11

$1 \quad 1$

$\begin{array}{rr}6 & 14 \\ 1 & 1 \\ 0 & 0\end{array}$

$0 \quad 0$

$0 \quad 0$

11

$\begin{array}{rr}3 & 20 \\ 0 & 0 \\ 5 & 9\end{array}$

$\begin{array}{rr}4 & 11 \\ 0 & 0 \\ 0 & 0\end{array}$ 
Upper Emergent/Shrub Zone, Unplanted

species

Typha latifolia

Unknown Apiaceae

Unknown Asteraceae

Unknown Cyperaceae

Unknown Fabaceae

Unknown Juncaceae

Unknown Lamiaceae

Unknown Poaceae

Unknown Solanaceae

Unknowns

vitis sp.

Wahlenbergia marginata

\begin{tabular}{lrr} 
year & N & Cover \\
\cline { 2 - 3 } 1987 & 7 & 64 \\
1988 & 15 & 51 \\
1989 & 19 & 99 \\
1987 & 0 & 0 \\
1988 & 4 & 75 \\
1989 & 0 & 0
\end{tabular}

1987

1988

1989

1987

1988

1989

1987

1988

1989

1987

1988

1989

1987

1988

1989

1987

1988

1989

1987

1988

1989

1987

1988

1989

1987

1988

1989

1987

1988

1989
64

51

99

0

75
0

$0 \quad 0$

6

5

1

10

2

$10 \quad 87$

$11 \quad 54$

$11 \quad 156$

$0 \quad 0$

$\begin{array}{ll}1 & 3 \\ 0 & 0\end{array}$

$9 \quad 37$

33

2

$39 \quad 569$

$23 \quad 339$

10

34

10

0

0

70

19

$\begin{array}{rl}14 & 19 \\ 7 & 19\end{array}$

$0 \quad 0$

$4 \quad 140$

$4 \quad 37$

$0 \quad 0$

$\begin{array}{ll}1 & 2 \\ 0 & 0\end{array}$ 

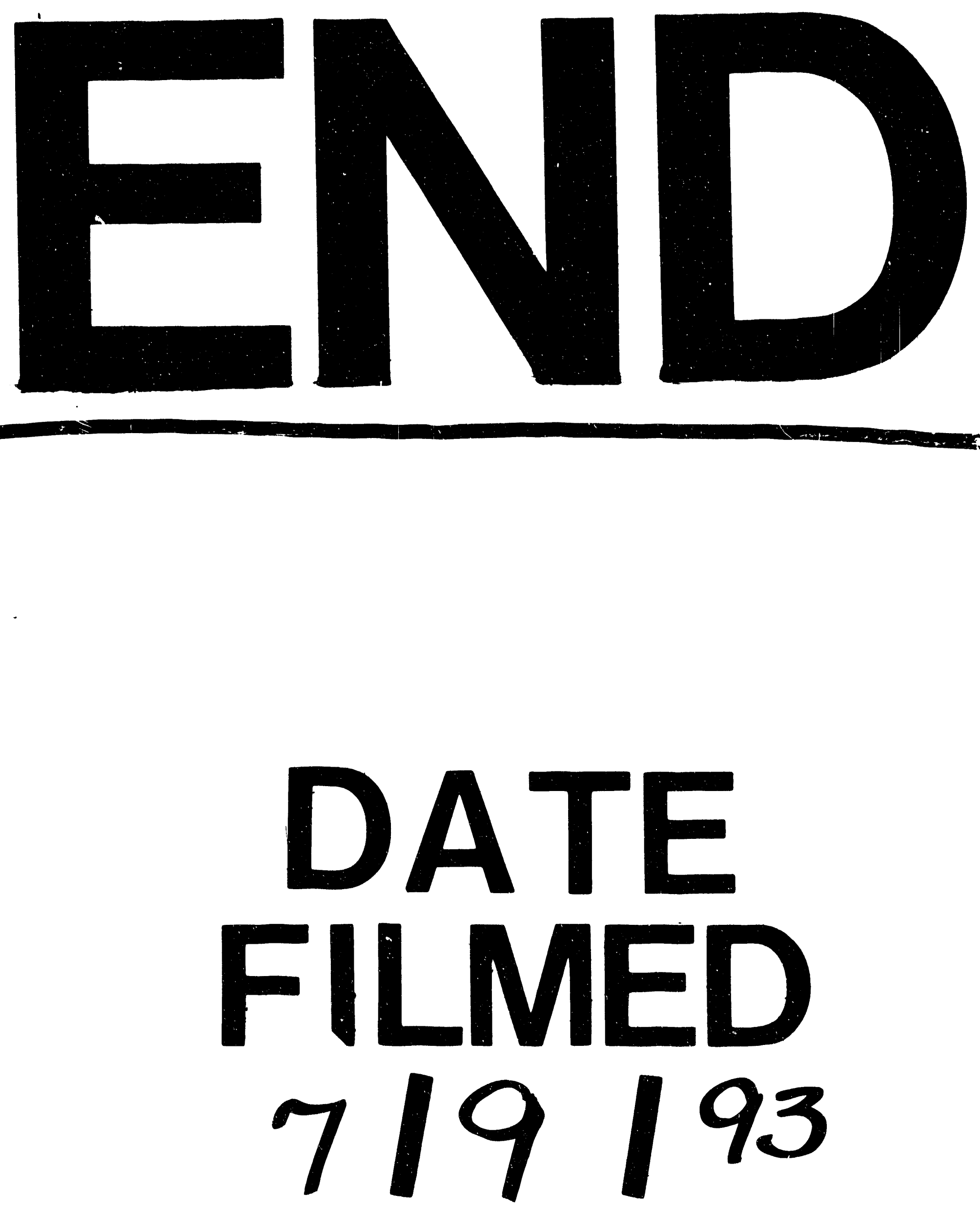

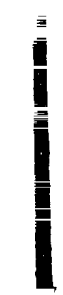

